Proc. Indian Acad. Sci. (Earth Planet. Sci.), Vol, 95, No. 1, March 1986, pp. 47-73. (C) Printed in India.

\title{
Sub-seasonal scale fluctuations of the ITcz over the Indo-Pacific region during the summer monsoon season. Part I: Features over the Indian region
}

\author{
D R SIKKA*, D K PAUL, V R DESHPANDE, V R MUJUMDAR and P V \\ PURANIK \\ Indian Institute of Tropical Meteorology, Pune 411005 , India \\ *Present address: International toga Project Office, 325 Broadway, Boulder, Colorado 80303, USA
}

MS received 15 April 1985; revised 14 November 1985

\begin{abstract}
Monex-79 and ISMEX-73 data have been analysed to study the sub-seasonal scale fluctuation of near equatorial oceanic intertropical convergence zone (ITCz) over the North Indian ocean during the summer monsoon of 1979 and 1973. The oceanic ITCZ is characterised by a narrow shear zone between the equatorial westerlies and the tropical easterlies, associated with organised convective clouds. Synoptic analysis presented in this paper shows the steady northward propagation of the oceanic IrCz from its near equatorial position $\left(5-10^{\circ} \mathrm{N}\right)$ to the continental position $\left(20-25^{\circ} \mathrm{N}\right)$ during the onset and mid-season revivals of monsoon after breaks. The northward propagation is initiated by the strengthening of the equatorial westerlies which result in the intensification of the shear zone and the embedded disturbances. The establishment of the northward propagating mode near normal monsoon trough position over the continent characterises the active phase of monsoon. As the monsoon cycles from active to weak/break phase, the monsoon trough (continental ITcz) dissipates near the foothills of the Himalayas and the oceanic IrCZ gets emphasised once again near the equatorial region. The major phase changes in the ITCZ occur at an interval of about $30-50$ days which dominantly control the intra-seasonal fluctuation of the Indian summer monsoon. The paper also discusses the characteristic features of the oceanic Ircz during different phases of the monsoon.
\end{abstract}

Keywords. Monex-79; ISMEX-73; intertropical convergence zone; maximum cloud zone; subseasonal scale fluctuations; preonset; onset and mid-season revival of monsoon.

\section{Introduction}

During the northern hemisphere spring season (May), a quasi-stationary zone of convergence (ITCZ) between the equatorial westerlies and the tropical easterlies, with maximum cyclonic vorticity, exists in the lower troposphere over the equatorial Northern Indian ocean. In the satellite cloud photographs an east-west oriented belt of a maximum cloud zone (MCZ) also exists near the equatorial region which almost coincides with the quasi-stationary position of the ITCZ during the spring season. To the north of the MCz, over the plains of India (where the summer heattrough is in the process of getting established) the skies are mostly clear. Questions have been raised in the GARP document (wMO 1976) as to (i) what happens to this spring season near equatorial ITCZ with the onset and advance of summer monsoon over India and (ii) whether it loses its identity in the equatorial position during the established phase of the monsoon under the influence of the continental monsoon trough?

One of our objectives in this paper is to provide an answer to the afore-mentioned questions through the examination of synoptic weather and satellite picture data over the Indo-Pacific region. Simultaneously we also propose to look into the activity and 
the characteristics of the near-equatorial rrcz over the region of study. Our aim is also to provide some understanding of the linkage between epochs of intensification/weakening of the ITCZ over the two oceanic regions in the evolution of the monsoon system especially the low frequency intra-seasonal ones. The study is primarily based mainly on the Summer Monex data for the season of 1979, which had the best data coverage so far achieved for the regions. It also examines the data of the season of 1973, year of another monsoon experiment, viz., Indo-Soviet Monsoon Experiment (ISMEX-73) in order to substantiate some of the results obtained from the study of the Summer Monex data.

Part I of the paper discusses the above mentioned questions for the Indian region (equator to $30^{\circ} \mathrm{N}$ and $60-100^{\circ} \mathrm{E}$ ). Part II of the paper besides studying the evolution and northward migration of the rTcz over the Northern West Pacific region (equator to $30^{\circ} \mathrm{N}$ and $110-140^{\circ} \mathrm{E}$ ) also discusses the interactions between the two regions on synoptic and sub-seasonal scales.

Section 2 deals with the methodology adopted for the data analysis. Section 3 discusses the sequence of major synoptic events, which occurred during different phases of the monsoon over India for the two seasons under study and $\$ 4$ explores answers to the aforementioned questions. The characteristics of the oceanic rTCZ and its vertical structure at the stages of pre-onset, onset and mid-season revival of the monsoon are discussed in $\$ 5$. The results are summarised in $\$ 6$.

\section{Data and methodology adopted}

Daily aerological data of the www stations and the data obtained from special Summer Monex research ships during Monex-79 and ISMEX-73 are used in this study. Most of the research flights during the Monex-79 were undertaken between 05 and $10 z$. The research ships and the land stations data used are corresponding to 06 and $12 z$ respectively. Satellite mosaics by us weather satellites are utilised to delineate the daily latitudinal position of the $\mathrm{MCZ}$. As we are concerned with the description of large scale characteristics of the ITcz, we believe that ( 3 to $6 \mathrm{hr}$ ) non-uniformity in the time of data coverage may not seriously hamper our results. The data have been analysed basically in three ways:

(i) analyses of meridional sections/time sections, of the observed data.

(ii) analyses of the wind, temperature and moisture fields at 850,700 and $500 \mathrm{mb}$ and other relevant parameters obtained at $2^{\circ}$ latitude-longitude grid intervals.

(iii) Daily latitudinal position of the $\mathrm{MCZ}$ and the trough at $700 \mathrm{mb}$ (representative of location of $\mathrm{rTCZ}$ ) at $70^{\circ}$ and $90^{\circ} \mathrm{E}$ corresponding to the North Indian Ocean, and at $120^{\circ}$ and $140^{\circ} \mathrm{E}$ corresponding to the monsoonal belt of the West Pacific Ocean.

The study mostly refers to $700 \mathrm{mb}$, as this level is considered to best reflect the low and middle level features of the rTCZ and monsoon activity. The grid points covered by the longitudes 66 to $80^{\circ} \mathrm{E}, 80-96^{\circ} \mathrm{E}$ and $110-140^{\circ} \mathrm{E}$ between equator and $20^{\circ} \mathrm{N}$ are referred to in the paper as pertaining to the Arabian sea, Bay of Bengal and the Northern West Pacific Ocean regions respectively. All the parameters were averaged over the respective longitudinal belts to determine the large scale characteristics of the ITCZ over the respective regions. 


\section{Discussion of major synoptic epochs over the Indian region}

The summer monsoon season evolves through different phases, viz., onset and northward advance of monsoon, established, and withdrawal of the monsoon. The pre-onset phase begins from early May. The advance of the monsoon is reckoned with the first northward migration of the equatorial westerlies. The established monsoon phase, which is usually the July-August period, is characterised by the active-break cycle during which the rainfall fluctuates, from ample over most of India (active) to deficient over the central parts of the country (break). Activity of the monsoon on a day to day basis is modulated by the synoptic scale transient disturbances. In the following sub-sections we discuss some of these aspects briefly for the two seasons under study.

\subsection{Season of 1979}

3.1a Pre-onset phase: In the beginning of May 1979, ITCZ was quite active in the equatorial Bay of Bengal and a cyclonic storm formed on 7 May near $7^{\circ} \mathrm{N}$ and $88.5^{\circ} \mathrm{E}$ which moved northwest and struck the coast on 12 May. A temporary surge in the lower tropospheric equatorial westerlies occurred under the influence of this development during 7 May to $17 \mathrm{May}$. The ITCZ activity reverted to the equatorial region after the storm had weakened. Successive passage of active western disturbances across Northern India and the associated equatorwards penetration of the sub-tropical westerlies (Sikka 1981) during the second half of May inhibited the formation and intensification of the seasonal trough along the Gangetic plains. Figures la and $b$ depict the average anomaly of the daily sea level pressure over India for the period 26 May to 5 June and the pressure distribution for the period. Figure lc shows the $700 \mathrm{mb}$ wind flow on a typical day (31 May) during the period. Prominent features in the second half of May, 1979, were the highly above-normal pressure $(\geqslant 6 \mathrm{mb})$ over the region of seasonal low pressure and over Northwestern and Central India and the existence of a marked high pressure cell at sea level over the Arabian sea. The shear zone at $700 \mathrm{mb}$ level between equatorial westerlies and subtropical easterlies over Arabian sea was along $5-7^{\circ} \mathrm{N}$. This was also associated with a zonally oriented band of maximum cloud $\left(\mathrm{MCZ}\right.$ ) along about $4^{\circ} \mathrm{N}$ (figure ld). Cloud clusters occasionally formed in the $\mathrm{MCZ}$ and moved in a general westerly direction. This $\mathrm{MCZ}$ could be identified with the position of the rTcz during the pre-onset phase. During this period the Gangetic plain and Central India were mostly cloud free except during the passage of a western disturbance.

3.1b Onset and advance phases: (i) Synoptic aspects-Figures $2 \mathrm{a}$ and $\mathrm{b}$ show the average anomaly of daily sea level pressures over India and the average sea level pressure distribution for the period 6 to 8 June, and figure $2 \mathrm{c}$ depicts the wind flow at $700 \mathrm{mb}$ for 7 June. From the end of May to the beginning of the 2 nd week of June lowering of pressure by about 6 to $8 \mathrm{mb}$ over Central and Northern India and increase in the pressure gradient between the equatorial region and Central India are noticeable from the data presented in figures $1 a$ and $b$ and figures $2 a$ and $b$. Similarly the shearzone over the SE Arabian sea (figure $2 \mathrm{c}$ ) and the associated MCZ (figure 2d) are also well marked than the same features shown in figures $1 \mathrm{c}$ and $\mathrm{d}$. Figure 3 shows the meridional time-section at $700 \mathrm{mb}$ for wind, temperature and relative humidity during 

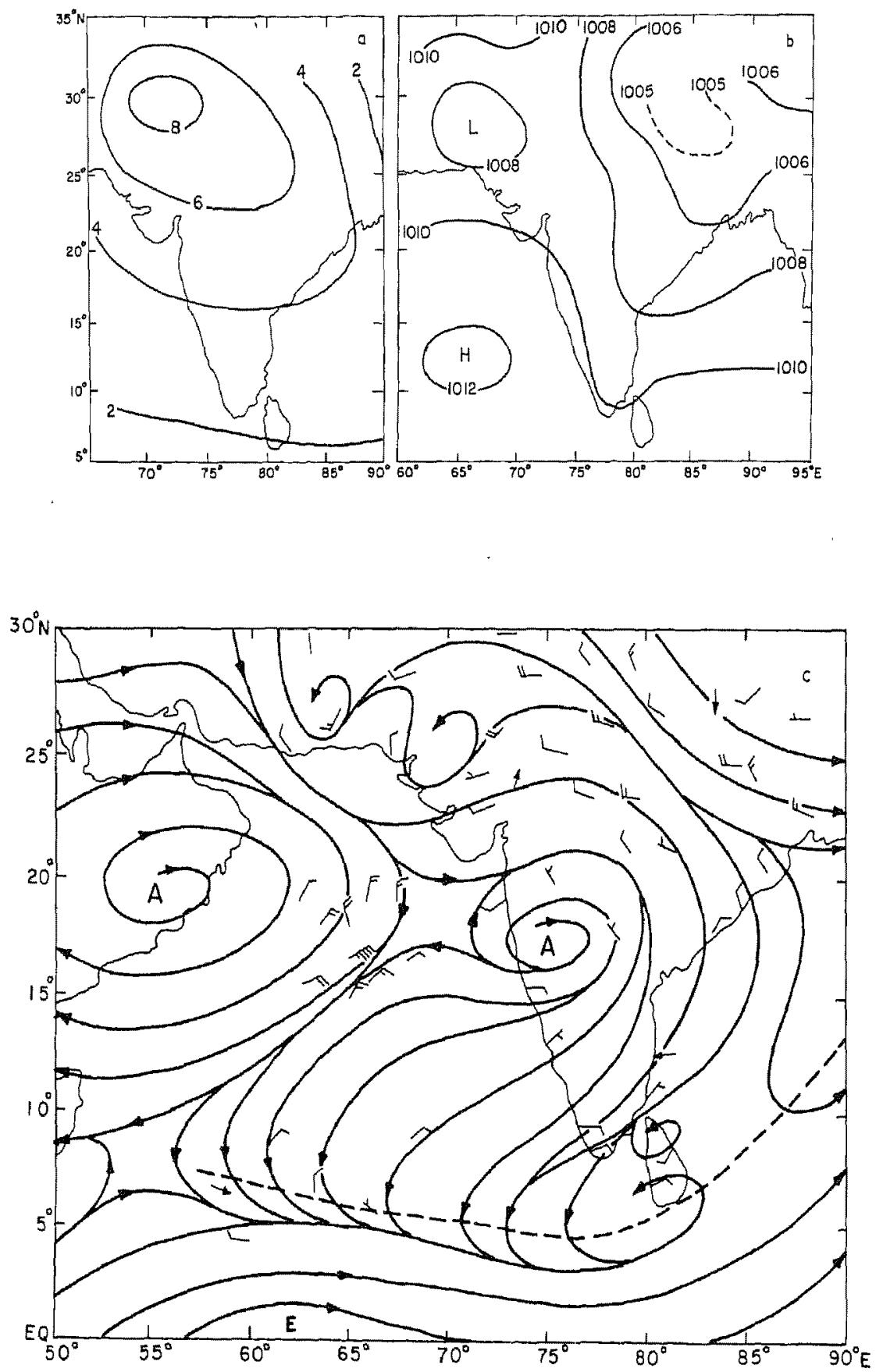

Figure 1. a-c. For captions, see p. 51 

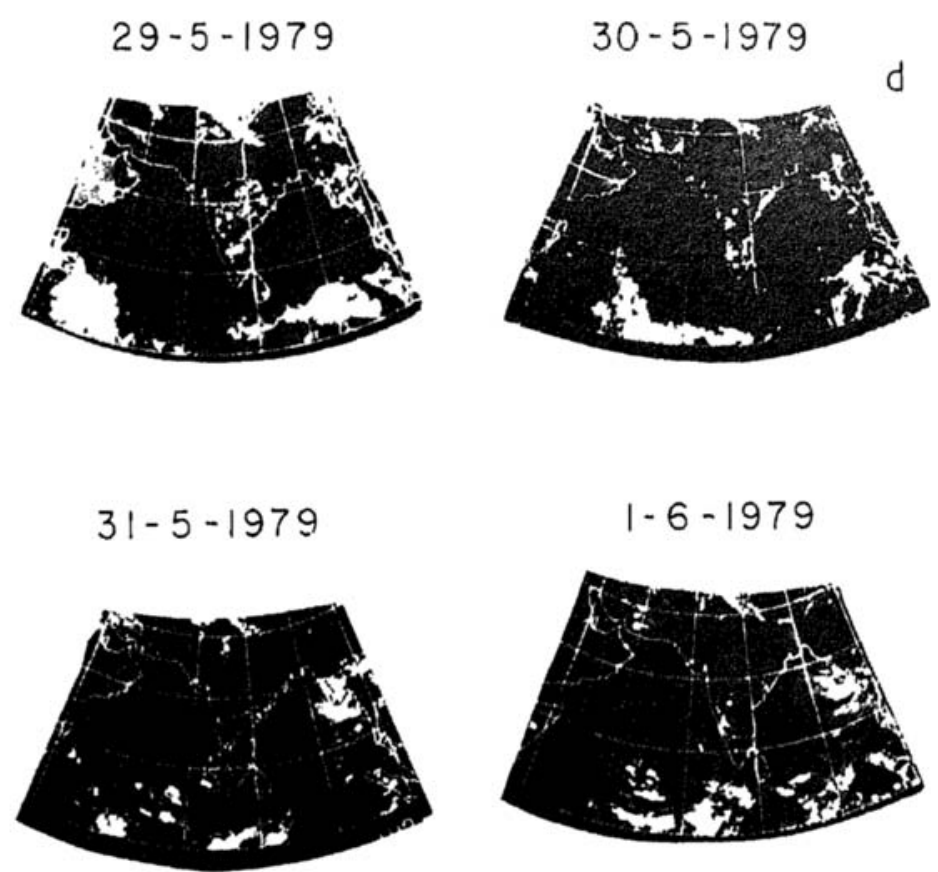

Figure 1a. Daily sea level pressure anomaly averaged for the period 26 May to 5 June 1979. b. Sea level pressure distribution averaged for the same period. c. Wind flow at $700 \mathrm{mb}$ for 31 May 1979, 00 GMT. d. Satellite cloud imageries (visible) for the period 29 May to I June, 1979.

4 to 20 June. It is seen that prior to the onset of the monsoon, the shear zone fluctuated along about $6^{\circ} \mathrm{N}$ upto 9 June. The figure also shows that the equatorial westerlies were more moist and were somewhat cooler than the air of continental origin to the north. The wind-shifts over the location of the Russian ships between 4-5 June and 8-9 June suggested the passage of cyclonic disturbances within the ITCZ (Bhide et al 1982). The latter circulation intensified on 14 June while it moved northward. About the time of its formation and its intensification, cross-equatorial wind surges occurred over the West Arabian sea on 8 June and 11 June and the equatorial westerlies abruptly strengthened over the Arabian sea during 12-14 June. Formation of the monsoon onset vortex has been discussed in detail by Krishnamurty et al (1981). The meridional section (figure 3) shows the northward progression of the shear zone and the belt of stronger westerlies from its pre-onset phase position over the Southern Arabian sea on 9 June to about $20^{\circ} \mathrm{N}$ on 20 June.

Figure 4 which is a longitudinal time section along $20-25^{\circ} \mathrm{N}$ for the pressure anomaly for the period 15 June to 7 July shows markedly above-normal pressure over the eastern part of the section in the middle of June followed by a period of negative pressure anomaly during 24 June to 3 July. It was in the latter period that the monsoon advanced over Central and Northeast India due to the passage of over-lapping monsoon disturbances. The rainfall distribution on 12 July when the monsoon has covered the entire country, is shown in figure 5.

(ii) Northward propagation of $M C Z$-Figure 6 shows the daily latitudinal position of the $700 \mathrm{mb}$ trough and the axis of the $\mathrm{MCZ}$ along $70^{\circ} \mathrm{E}$ and $90^{\circ} \mathrm{E}$ for June. The two 

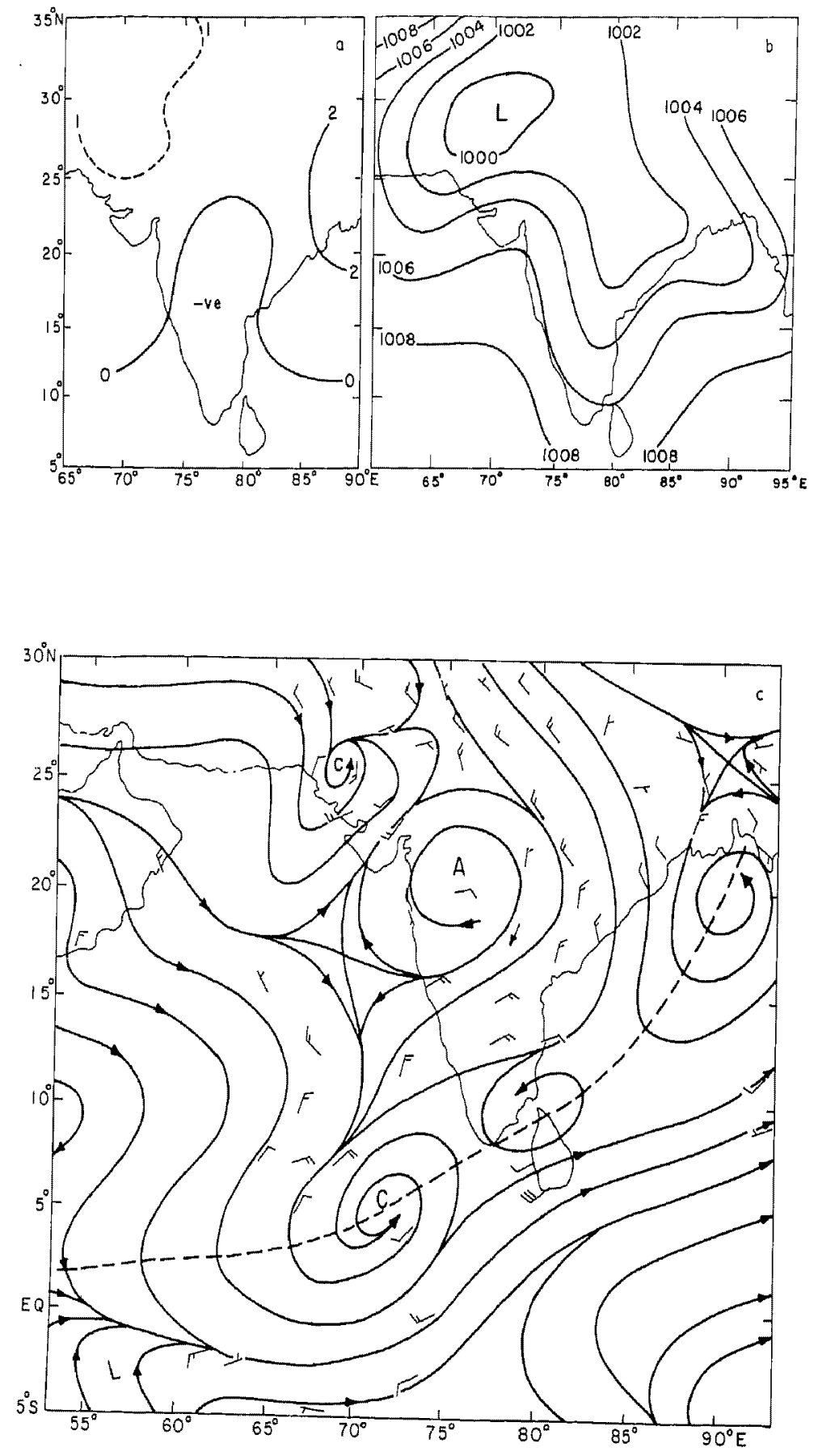

Figure 2. a-c. For captions see p. 53 


$$
8-6-1979
$$

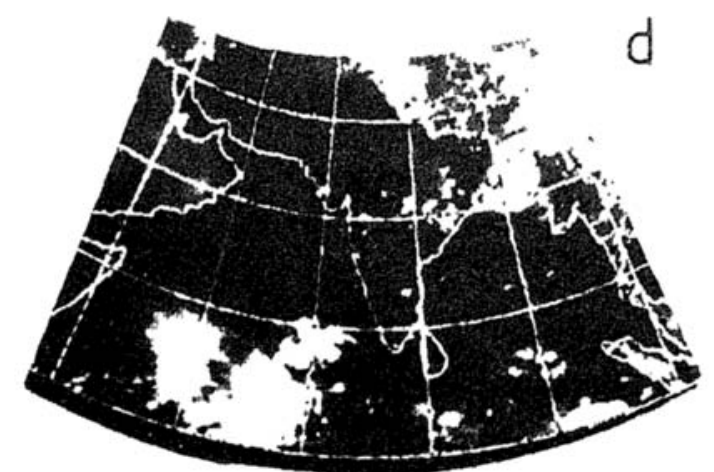

Figure 2a. Daily sea level pressure anomaly averaged for the period 6 to 8 June 1979. b. Sea level pressure distribution averaged for the same period. c. Wind flow at $700 \mathrm{mb}$ for 7 June 1979, 00 GMT. d. Satellite cloud imagery (visible) for 8 June 1979.

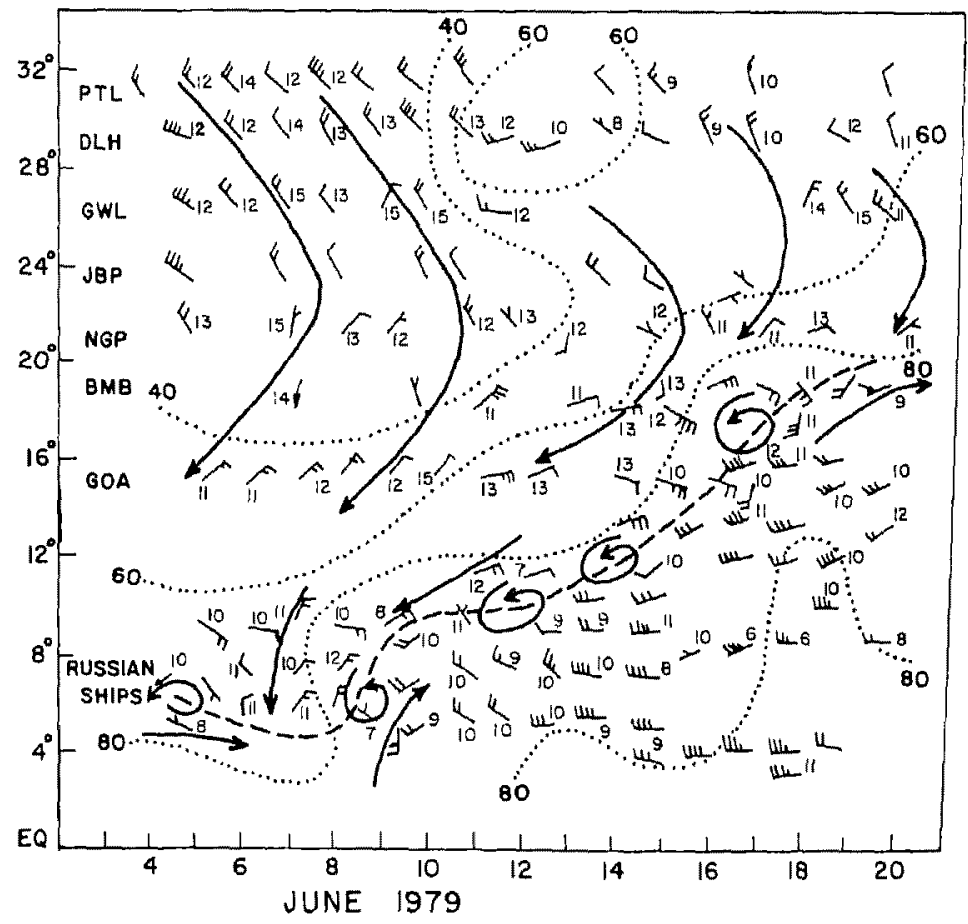

Figure 3. Meridional-time section at $700 \mathrm{mb}$ of wind, temperature and relative humidity along the belt $66-80^{\circ} \mathrm{E}$ during 4 to 20 June 1979. 


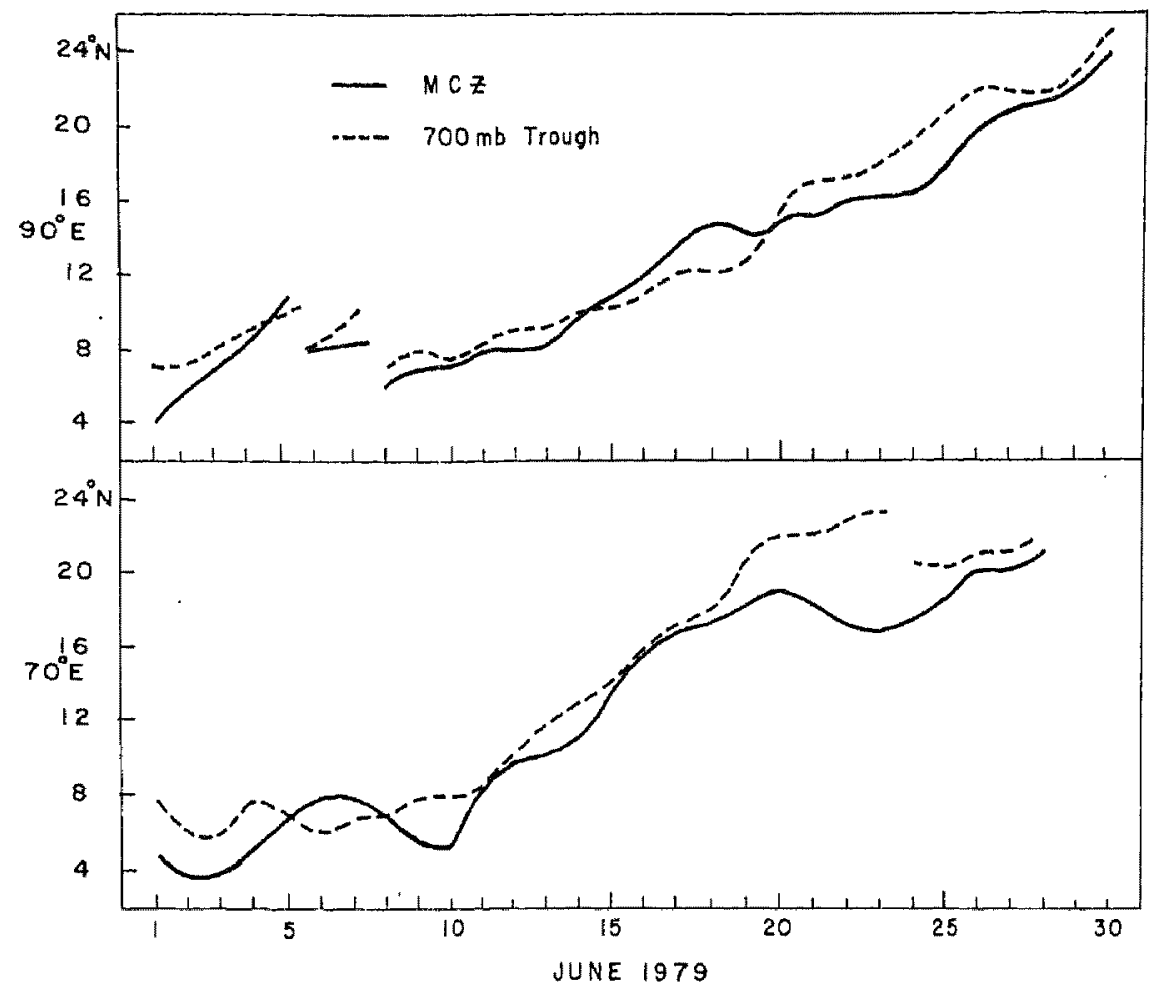

Figure 6. Daily latitudinal position of axis of maximum cloud zone (MCZ) and $700 \mathrm{mb}$ trough line along $70^{\circ} \mathrm{E}$ and $90^{\circ} \mathrm{E}$ for June 1979 .

during 1 to 5 May and shows a band of well organised convective clouds within the MCZ extending from the Southwest Bay off the Southeast Sri Lanka coast $\left(8^{\circ} \mathrm{N}\right)$ to the east central Bay and the adjoining North Andaman sea off the Burma coast. A west/northwestwards movement of this cloud band is also seen in the figure. The $\mathrm{MCZ}$ and the $700 \mathrm{mb}$ trough fluctuated between 8 and $12^{\circ} \mathrm{N}$ and 8 and $15^{\circ} \mathrm{N}$ respectively during 1 to 10 May along the $90^{\circ} \mathrm{E}$ longitude (figure 10). Synoptic scale disturbances formed within the rrcz during the period, moved west/north-westwards across the Bay of Bengal causing a northward movement of the $\mathrm{MCZ}$ and the $700 \mathrm{mb}$ trough. Thus the first organised northward movement of the MCZ in the Bay of Bengal sector can be considered to take place during the first fortnight of May. During the second fortnight of May, pressure over most of India was above normal till 27 May and below normal during the last few days of the month.

3.2b Onset and advance phase: (i) Synoptic aspects-Figure 11 shows the meridional-time section at $700 \mathrm{mb}$ of wind, temperature and relative humidity during $21 \mathrm{May}$ to 11 June in the Arabian sea sector (along $55-75^{\circ} \mathrm{E}$ ). The figure shows that the shear-zone associated with the rrcz fluctuated between 7 and $9^{\circ} \mathrm{N}$ during 22 to 29 May with cyclonic systems embedded within it during 22-23, 24-25 and 28-29 May. The ITCZ weakened on 29 May and it lay close to the equator till the beginning of June. Thus, the first spurt of ITCZ activity in the Southeast Arabian sea, which began on 22 May was rather a short-lived one (about a week). 


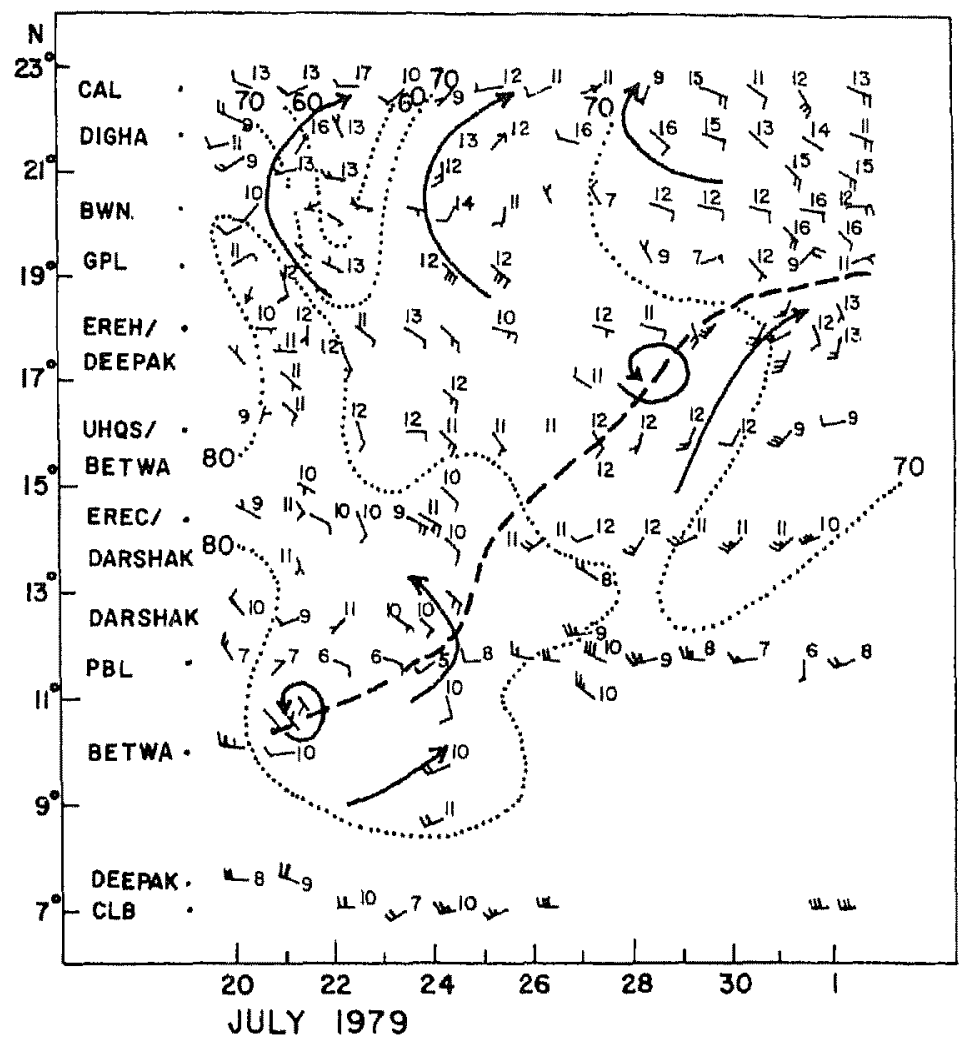

Figure 7. Meridional-time section at $700 \mathrm{mb}$ of wind, temperature and relative humidity along the belt $85-90^{\circ} \mathrm{E}$ during 20 July to 1 August 1979 .

Sea-level pressure over Northwest India and adjacent Pakistan was above normal during 30 May to 3 June and became below normal on 4-5 June. The equatorial convergence zone became active once again on 4 June. A cyclonic circulation formed within it on 4-5 June and the associated shear-zone was loacted near $10^{\circ} \mathrm{N}$. Equatorial westerlies abruptly intensified to $30-35 \mathrm{~m} / \mathrm{sec}$ on $6 \mathrm{June}$. As the system began to move northwards, strong (cold and moist) cross equatorial flow rushed towards the Central and East Arabian sea and led to the intensification of the cyclonic system to a depression on 6 June and cyclonic storm on 8 June. The ITCz progressively moved northward along with the storm bringing the equatorial westerlies to about $20^{\circ} \mathrm{N}$ by 9 June.

The above description brings out that the onset process along the west coast in 1973 occurred twice- the first one-a temporary one during 23-27 May and the secondthe regular one between 4-9 June.

(ii) Northward progression of $M C Z$-Figure 12 shows that at the time of temporary onset of monsoon over Kerala (23-27 May), the $700 \mathrm{mb}$ trough and axis of MCZ fluctuated between 6 and $10^{\circ} \mathrm{N}$, over the Arabian sea $\left(70^{\circ} \mathrm{E}\right)$ and the Bay of Bengal $\left(90^{\circ} \mathrm{E}\right)$. With the regular onset and advance of monsoon, the $700 \mathrm{mb}$ trough and the 


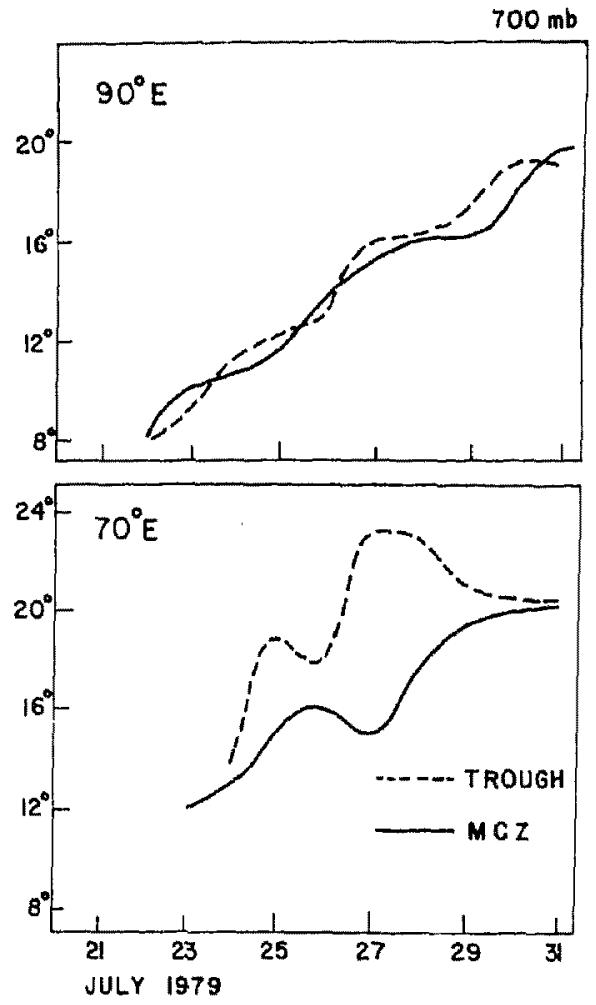

Figure 8. Daily latitudinal position of axis of $\mathrm{MCz}$ and $700 \mathrm{mb}$ trough line along $70^{\circ} \mathrm{E}$ and $90^{\circ} \mathrm{E}$ for $21-31$ July 1979.

axis of MCZ marched progressively northward from $9-10^{\circ} \mathrm{N}$ on 4 June to $20^{\circ} \mathrm{N}$ on 9 June along both the longitudes.

There was a lull in the further advance of monsoon after 13 June. The seasonal trough moved rapidly northwards, near the foothills of the Himalayas and a lull prevailed in the monsoon-activity during the second half of June. The ITCZ remained weak as no perturbation formed within it and both the Arabian sea and the Bay of Bengal were devoid of any organised convective cloudiness. A series of western disturbances moved across Northwest India during this period.

Figure 13 shows the daily position of the $700 \mathrm{mb}$ trough and the axis of $\mathrm{MCZ}$ along $70^{\circ} \mathrm{E}$ and $90^{\circ} \mathrm{E}$ (top part) and a meridional time section (wind, temperature and relative humidity) at $700 \mathrm{mb}$ along $55-75^{\circ} \mathrm{E}$ (Arabian sea) and along $80-93^{\circ} \mathrm{E}$ (Bay of Bengal for the period 28 June to $10 \mathrm{July}$ ). A cyclonic circulation which formed on 28-29 June reactivated the ITCZ near $18^{\circ} \mathrm{N}$. This system as well as a trough off the west coast of India during 27 June to 7 July, revived the monsoon activity and led to its further northward advance. The monsoon covered the entire country by 6 July, under the influence of two overlapping depressions which affected the country during 6 to 9 July. The ITcz by this time ( $6 \mathrm{July}$ ) had occupied its near normal position i.e. $20-22^{\circ} \mathrm{N}$ and it remained active with minor fluctuations around this position till the third week of July. The top part of figure 13 shows the progressive northward march of $700 \mathrm{mb}$ trough 
Fluctuation of ITCZ over Indo-Pacific region

59

$$
1-5 \cdot 1973
$$

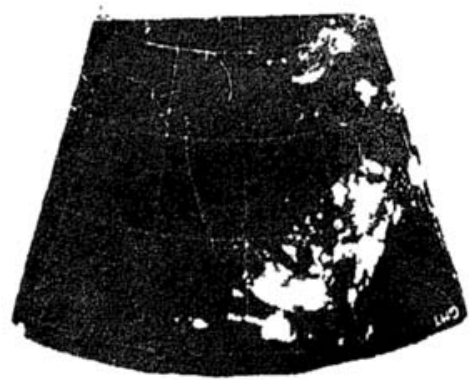

$$
2-5-1973
$$

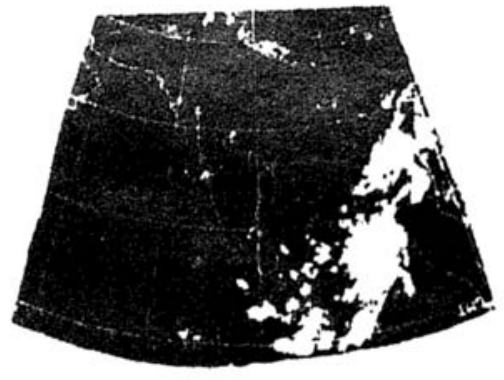

$$
3-5-1973
$$

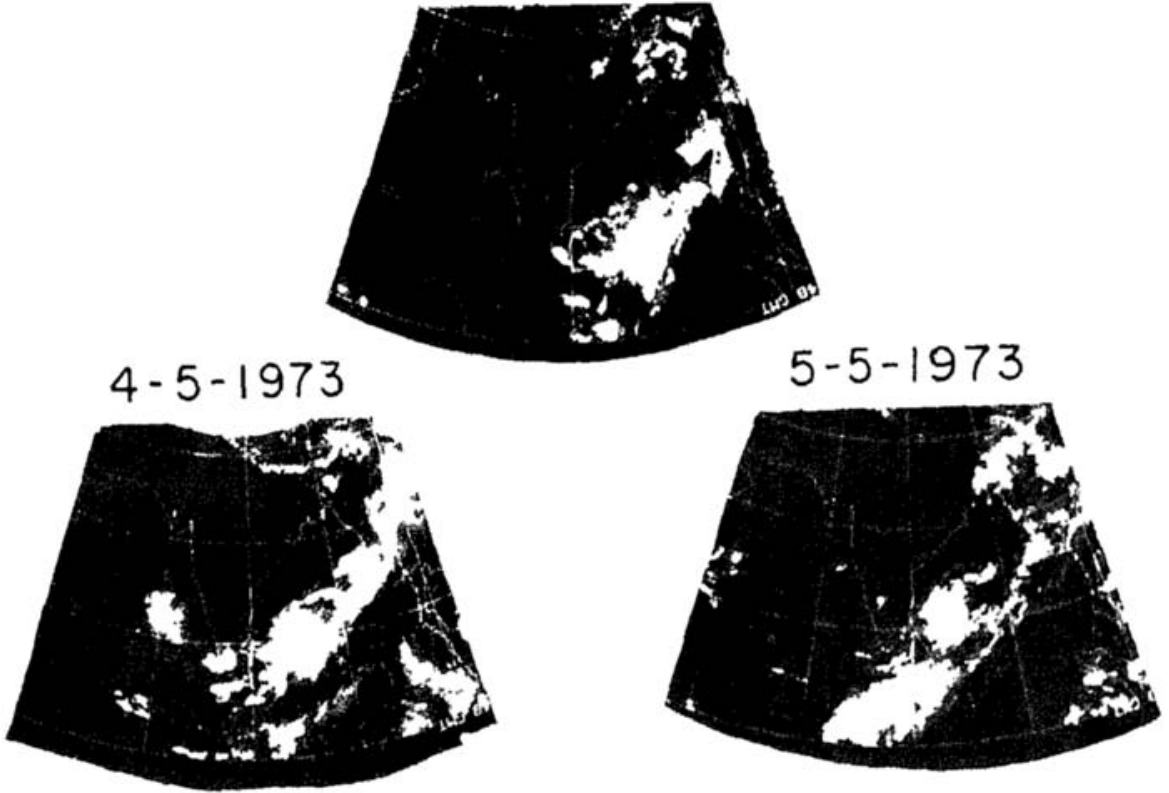

Figure 9. Satellite cloud imageries (visible) for the period 1 to 5 May 1973.

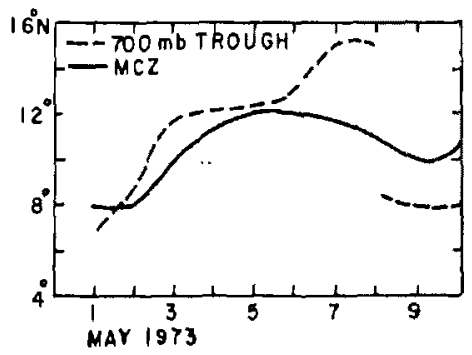

Figure 10. Daily latitudinal position of axis of $\mathrm{MCZ}$ and $700 \mathrm{mb}$ trough line along $90^{\circ} \mathrm{E}$ for 1-10 May 1973. 


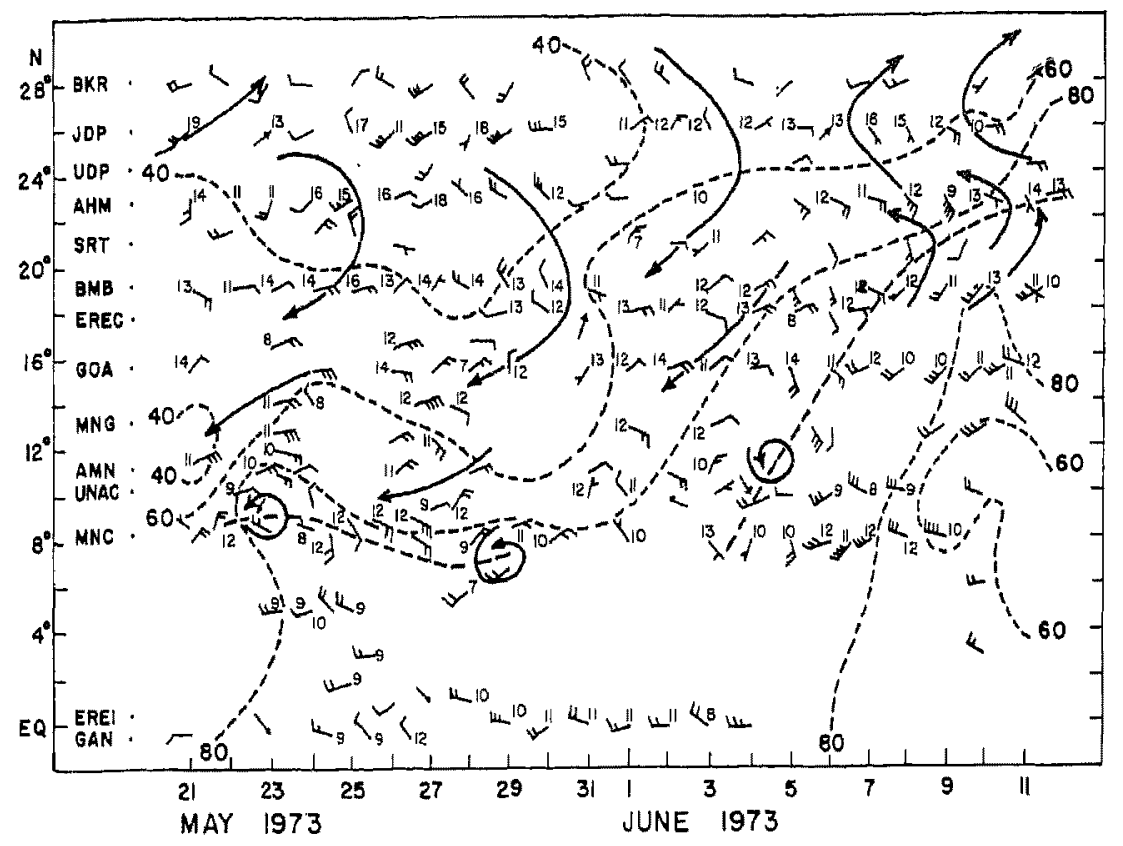

Figure 11. Meridional-time section at $700 \mathrm{mb}$ of wind temperature and relative humidity along the belt $55-75^{\circ} \mathrm{E}$ during 21 May to 11 June 1973.

and the $\mathrm{MCz}$ along $70^{\circ} \mathrm{E}$ and $90^{\circ} \mathrm{E}$ from $14-16^{\circ} \mathrm{N}$ on 28 June to $20-22^{\circ} \mathrm{N}$ on $8-10 \mathrm{July}$. Thereafter, during 12 to 22 July movement of two strong systems, a deep depression and a severe cyclonic storm, from the Bay of Bengal to the central parts of India kept the monsoon active over most of the country.

3.2c Revival of the monsoon after a 'break' in the established phase: Typical 'break' monsoon patterns of pressure and winds prevailed over major parts of the country on 24 July and lasted till 1 August. The oceanic ITCZ appeared near 8-10 $\mathrm{N}$ on 2 August. This is seen in figure 14. The figure also shows that the ITCZ intensified and moved progressively northwards, reached $20^{\circ} \mathrm{N}$ on 7 August and was even further north of $25^{\circ} \mathrm{N}$ on 9 August. This was rather a very rapid northward progression which is also reflected in the northward movement of the axis of MCZ. The oceanic ITCZ again became active near $10^{\circ} \mathrm{N}$ on 8 August and started its northward progression. This is also noticed from the northward movement of the $\mathrm{MCz}$ from $7^{\circ} \mathrm{N}$ on 7 August to $15^{\circ} \mathrm{N}$ on 13 August.

The sequences of events described above clearly show that during the period 2-13 August, two successive meridional progressions of the oceanic ITCZ took place from the near-equatorial region. These events led to the revival or re-establishment of the monsoon activity over most parts of the country. In several respects the revival or reestablishment phase of the monsoon after a major break was similar to the multiple sequences of events which happened at the time of onset.

After the mid-season revival of the monsoon, overlapping disturbances formed over 


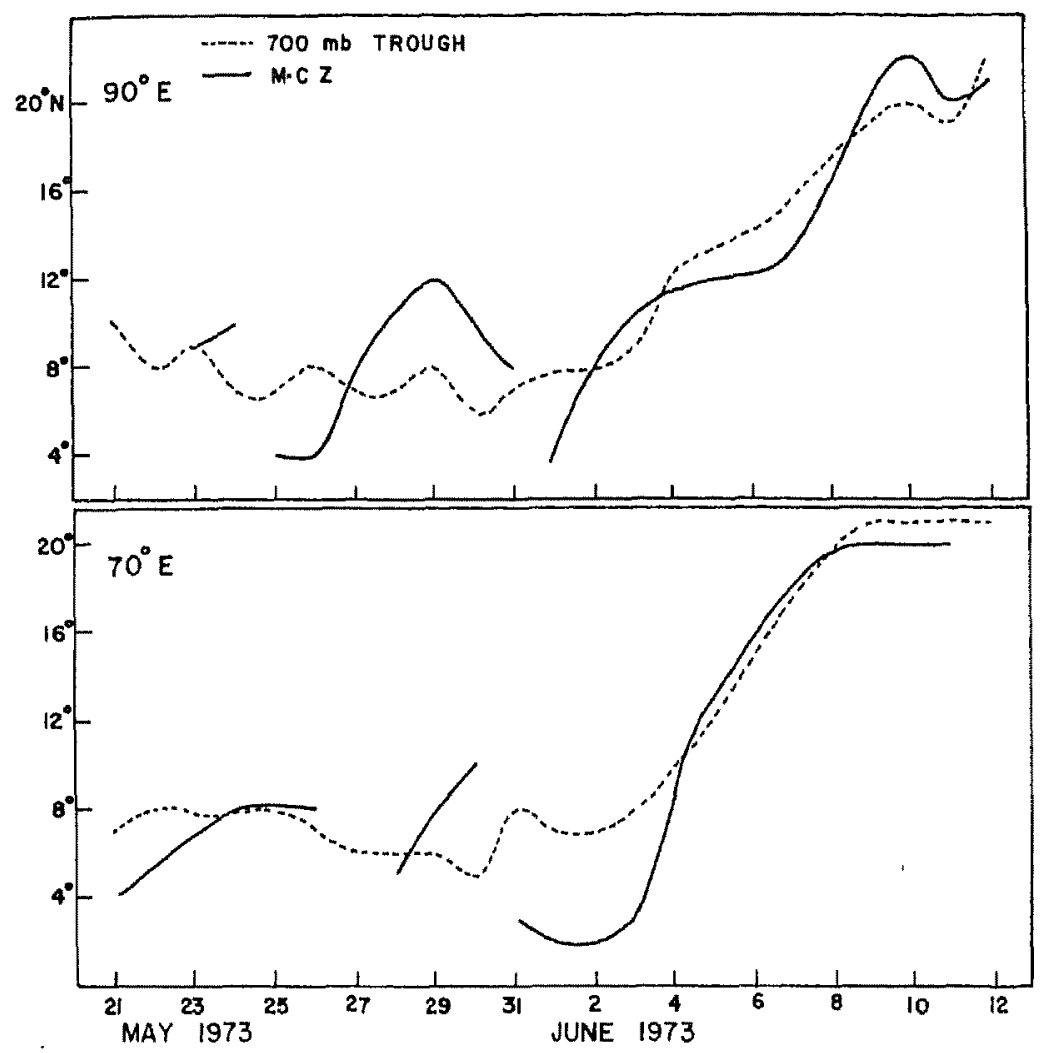

Figure 12. Daily latitudinal position of axis of $\mathrm{MCz}$ and $700 \mathrm{mb}$ trough line along 70 and $90^{\circ} \mathrm{E}$ for 21 May to 11 June 1973 .

the Bay of Bengal and over the land-locked monsoon trough which moved in a westerly or northwesterly direction. These systems maintained active monsoon conditions over the country for about a month.

\section{Discussion of results for the Indian monsoon region}

Based on the above sequential description of synoptic events during the two typical monsoon seasons, the onset, advance and active-break-active cycles of the Indian monsoon may be understood in the following way. The location of the near equatorial oceanic ITCZ during the spring season is such that the heated continental region lies to its north. However, in the early spring season the intensity of the heat source is not yet sufficiently developed to significantly influence the ITCZ and hence it is located in a quasi-stationary position over the warm equatorial waters. As the heating of the continental region and the overlying airmass progresses the seasonal, regional and planetary scale pressure systems of the summer monsoon begin to intensify. A stage is reached when the ircz is observed to respond to the intense heat source. This process is aided by the latent heat released within the organised convection associated with the oceanic Ircz and over the adjoining maritime continental region of Indonesia as well as 


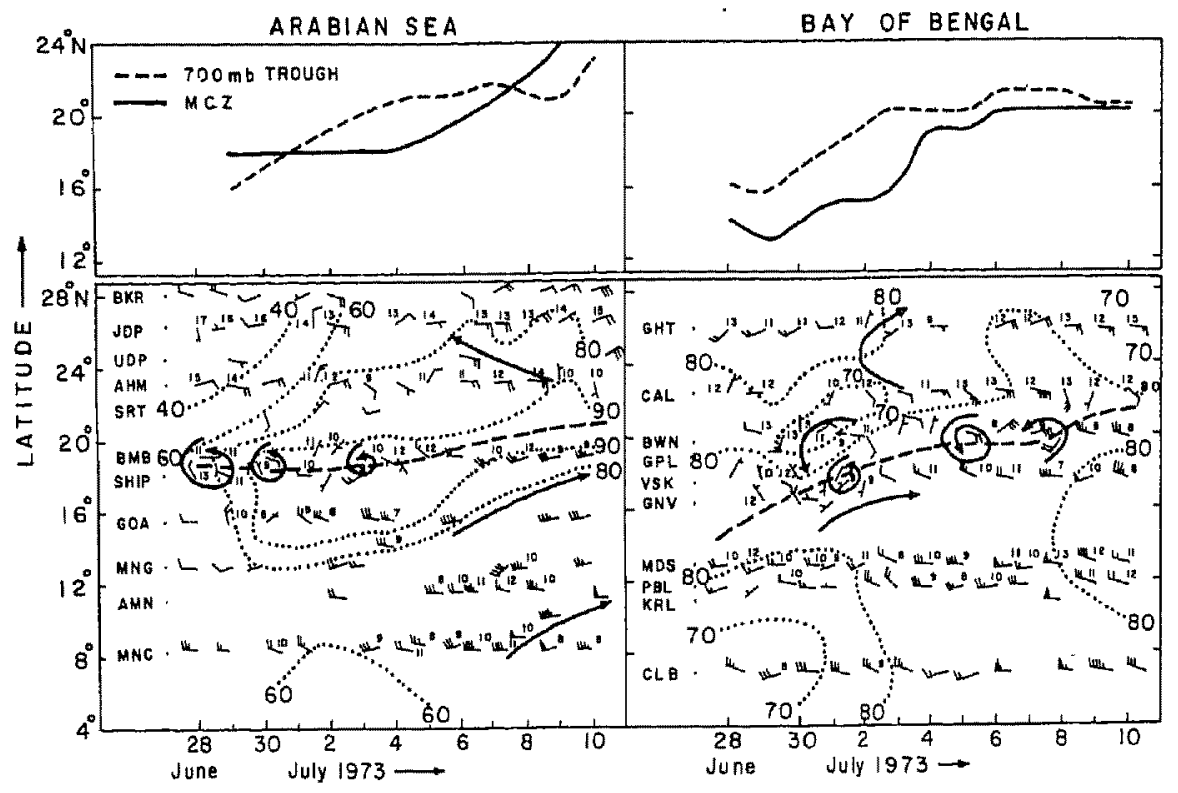

Figure 13. Meridional-time section at $700 \mathrm{mb}$ of wind, temperature and relative humidity along the belt $55-75^{\circ} \mathrm{E}$ (Arabian sea) and $80-95^{\circ} \mathrm{E}$ (Bay of Bengal) and daily latitudinal position of axis of $M C Z$ and $700 \mathrm{mb}$ trough (top part) along the longitude $70^{\circ} \mathrm{E}$ (Arabian sea) and $90^{\circ} \mathrm{E}$ (Bay of Bengal) for the period 28 June to 10 July 1973.

the Tibetan Plateau (Northeast India). Krishnamurty and Ramanathan (1982) have quantitatively discussed the role of different heating processes during the onset phase of the monsoon.

The synoptic events also suggest that under the large scale response of the continental thermal low and dynamical influence of transient perturbations forming within the ITCZ, strong cross-equatorial monsoonal flow is established over the northern equatorial Indian ocean at the time of the monsoon onset. Further intensification of the transient disturbances of the ITCZ follows and the entire system progressively moves northwards towards the seasonal heat trough which is by then well established over North India.

Further progress in the advance of the monsoon over other parts of India can be viewed as the replacement of the continental heat trough by the continental monsoon trough (continental ITCZ). This is so because before the onset of monsoon upto $20^{\circ} \mathrm{N}$, dry convective processes are dominant within the continental heat trough with the northward advance of the monsoon regional continental heat trough undergoes a transition to monsoon trough resulting in organised moist convection over the continental region of India.

As the monsoon trough moves further northward close to the foot of the Himalayas, 'break' or 'weak' monsoon conditions set in over the central parts of India with above normal pressure prevailing over the same region. During the transition from active to weak/break phase the oceanic Ircz once again identifies itself in the equatorial region, with its associated low level cyclonic disturbances and organised convection on the synoptic/large scale. Perturbations moving north/north-westwards within the ITCZ 


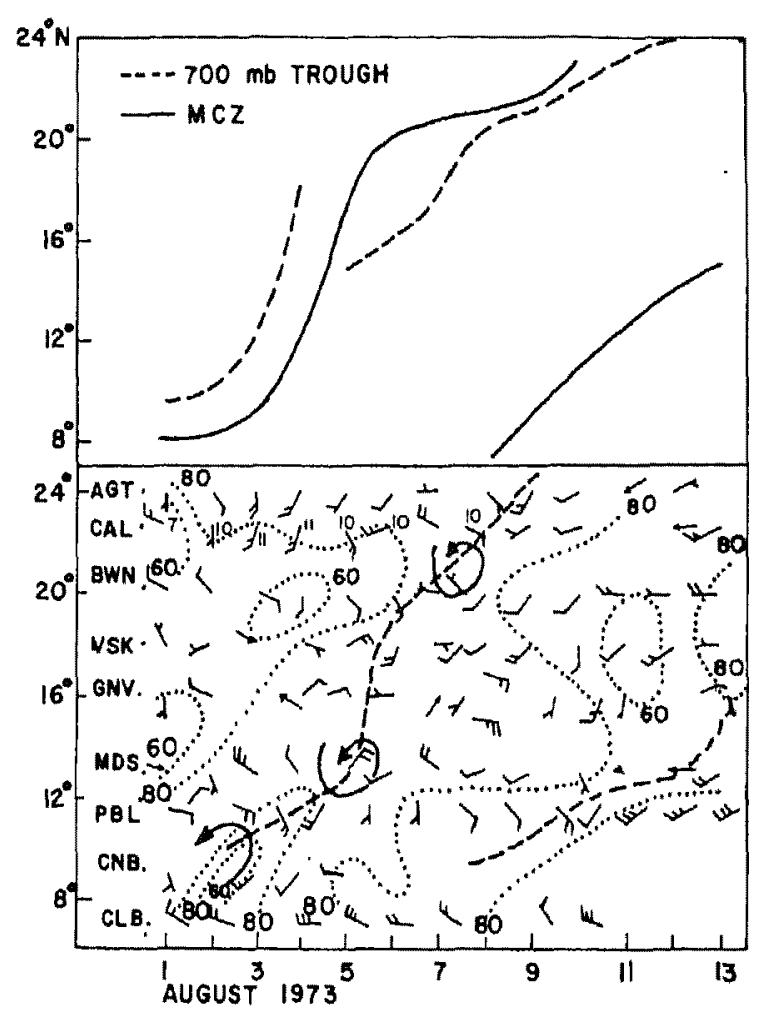

Figure 14. Meridional-time section at $700 \mathrm{mb}$ of wind, temperature and relative humidity along the belt $80-95^{\circ} \mathrm{E}$ and daily latitudinal position of axis of $\mathrm{MCZ}$ and $700 \mathrm{mb}$ trough (top part) for the period 1-13 August 1973.

establish the whole system once again from the equatorial region to its near normal position $\left(\sim 20^{\circ} \mathrm{N}\right)$ within a period of 7-10 days.

The existence and westward movement of the near equatorial cyclonic disturbances at $700 \mathrm{mb}$ during the 'break' period was first identified by Koteswaram (1950). Mukherjee and Natarajan (1968) also documented such sequences. Table 1 summarises the sequence of events which occurred in the seasons of 1979 and 1973. It shows the existence of 30-40 day periodicity between the epochs of intensification of the oceanic ITCZ. The active phase of the monsoon commences when the IrCZ is established over $20^{\circ} \mathrm{N}$ after its northward propagation from the near equatorial region. The active phase is maintained by overlapping formations of disturbances in the monsoon trough zone which may last for about two weeks, with some minor oscillation in the position of the monsoon trough and also the waxing and waning of its intensity. During this enveloping period of disturbances, good rainfall activity is maintained over India. After this the monsoon trough shifts to the foothills in a matter of 3-4 days and the oceanic IrCz begins to emphasise itself once again. If this happens in the middle 'of the monsoon season, the continental heat source once again becomes prominent and the oceanic ITCZ responds to it. When this happens in the middle of September, the autumn transition in the northern latitude is underway and hence this leads to the withdrawal of the monsoon from Northwestern India. As such the next northward excursion of the equatorial ITCZ is then limited to the latitudes of about $15^{\circ} \mathrm{N}$. 
Table 1. Dates and periodicity of epocts of strengthening of oceanic rrcz and its northward progression (with speed of movement) from the near equatorial position to its near normal position $\left(\approx 20^{\circ} \mathrm{N}\right)$ and the commencement of 'break' in monsoon.

\begin{tabular}{|c|c|c|c|c|c|c|}
\hline & \multirow[b]{2}{*}{ Epochs } & \multicolumn{2}{|c|}{$\begin{array}{c}\text { Dates (with latitudinal } \\
\text { position) on which }\end{array}$} & \multirow{2}{*}{$\begin{array}{l}\text { Time of } \\
\text { reaching } 20^{\circ} \mathrm{N} \\
\text { position and } \\
\text { latitudinal } \\
\text { distance } \\
\text { traversed }\end{array}$} & \multirow{2}{*}{$\begin{array}{l}\text { Speed of } \\
\text { northward } \\
\text { movement } \\
\text { of ITCz } \\
\text { (latitudes } \\
\text { per day) }\end{array}$} & \multirow[b]{2}{*}{$\begin{array}{c}\text { Break } \\
\text { monsoon } \\
\text { commenced }\end{array}$} \\
\hline & & $\begin{array}{c}\text { Ircz became } \\
\text { active near } \\
\text { the equatorial } \\
\text { region }\end{array}$ & $\begin{array}{l}\text { ITCz reached } \\
\text { its near normal } \\
\text { position } \\
\left(\sim 20^{\circ} \mathrm{N}\right)\end{array}$ & & & \\
\hline & I & $\begin{array}{l}11 \text { June } \\
\left(8^{\circ} \mathrm{N}\right)\end{array}$ & $\begin{array}{l}19 \text { June } \\
\left(20^{\circ} \mathrm{N}\right)\end{array}$ & $\begin{array}{l}9 \text { days } \\
\left(12^{\circ} \text { latitude }\right)\end{array}$ & $1.3^{\circ}$ & 20 July \\
\hline \multirow[t]{3}{*}{1979} & II & $\begin{array}{l}24 \text { July } \\
\left(12^{\circ} \mathrm{N}\right)\end{array}$ & $\begin{array}{l}31 \text { July } \\
\left(19^{\circ} \mathrm{N}\right)\end{array}$ & $\begin{array}{l}7 \text { days } \\
\left.\text { ( } 7^{\circ} \text { latitude }\right)\end{array}$ & $1.0^{\circ}$ & 19 August \\
\hline & $\begin{array}{l}\text { Periodicity } \\
\text { (days) }\end{array}$ & 44 & 43 & 一 & - & 31 \\
\hline & I & $\begin{array}{l}23 \text { May } \\
\left(8^{n} \mathrm{~N}\right)\end{array}$ & $\begin{array}{l}8 \text { June } \\
\left(20^{\circ} \mathrm{N}\right)\end{array}$ & $\begin{array}{l}16 \text { days } \\
\text { (12 latitude) }\end{array}$ & $0.7^{\circ}$ & 14 June \\
\hline \multirow[t]{4}{*}{1973} & II & $\begin{array}{l}29 \text { June } \\
\left(14^{\circ} \mathrm{N}\right)\end{array}$ & $\begin{array}{l}8 \text { July } \\
\left(20^{\circ} \mathrm{N}\right)\end{array}$ & $\begin{array}{l}9 \text { days } \\
\text { (6 } 6^{\circ} \text { latitude) }\end{array}$ & $0.7^{\circ}$ & 22 July \\
\hline & $\begin{array}{l}\text { Periodicity } \\
\text { (days) }\end{array}$ & 38 & 31 & - & - & 39 \\
\hline & III & $\begin{array}{l}2 \text { August } \\
\left(11^{\circ} \mathrm{N}\right)\end{array}$ & $\begin{array}{l}8 \text { August } \\
\left(21^{\circ} \mathrm{N}\right)\end{array}$ & $\begin{array}{l}5 \text { days } \\
\left(10^{\circ} \text { latitude) }\right.\end{array}$ & $2 \cdot 0^{\circ}$ & - \\
\hline & $\begin{array}{l}\text { Periodicity } \\
\text { (days) }\end{array}$ & 35 & 32 & - & - & - \\
\hline
\end{tabular}

Sikka and Gadgil (1980) have demonstrated the meridional propagation of cloudiness from near equatorial region to the monsoon trough region on the scale of about 30-40 day during the summer monsoon season. Yasunari $(1979,1980,1981)$ has also emphasised the $30-40$ day mode in the monsoon cloudiness. Krishnamurty and Subramaniam (1982) using filtered zonal wind data at $850 \mathrm{mb}$ have further revealed same quasi-periodicity in the zoral winds dominated by meridional propagation of trough ridge sequences from the equatorial region to the foothills of the Himalayas. Murakami et al (1983) also used filtered data to emphasise the low frequency oscillations in several features of the regional monsoon system. The detailed synoptic evidence presented in the present study confirms that the intra-seasonal fluctuations of the monsoon system is dominated by $30-40$ day mode.

\section{Characteristic features of the oceanic Ircz over the north Indian Ocean}

Godbole and Ghosh (1975) studied some features of the near equatorial ITcz along $55^{\circ} \mathrm{E}$ and $65^{\circ} \mathrm{E}$ over the Arabian sea during 23-28 May 1973, which period covered the 
temporary onset of the monsoon. We propose to document the characteristics of the near equatorial shear zone and also those of the superimposed synoptic scale disturbances during different phases of the monsoon for the two seasons. The data is presented in two ways, viz, (i) longitudinally averaged (based on a $2^{\circ}$ grid interval) characteristics for $700 \mathrm{mb}$ over the belt 66 to $96^{\circ} \mathrm{E}$ and (ii) average relative vorticity and divergence for the active regime of the large scale ITCZ to represent the disturbed part of the Ircz. Two sets of sequences are studied for each of the years corresponding to (i) the onset phase and (ii) the revival after a 'break' in the monsoon in the established phase. As aircraft reconnaissance and drop-sonde data were available for the sequences in the season of 1979, typical vertical structures of the ITCz are also studied for these sequences along suitable meridians for which the data were maximum.

\subsection{Large scale characteristics}

5.1a Pre-onset and onset phases of monsoon: Figures 15 and 16 show the meridional profiles of the longitudinally averaged temperature, relative humidity, zonal wind and relative vorticity at $700 \mathrm{mb}$ for three typical days in these phases for the two seasons. The profile of 7 and 10 June 1979 and 3 and 4 June 1973 define conditions during the pre-onset and just before the onset of monsoon. The profiles for 14 June 1979 and 7

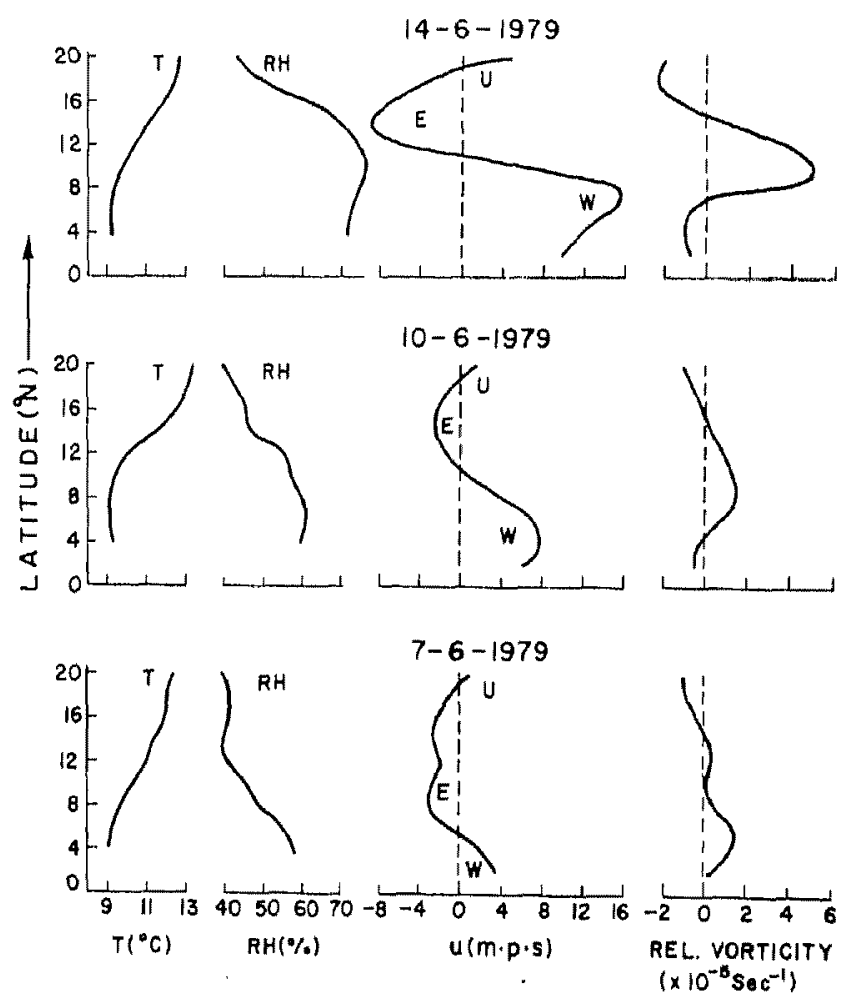

Figure 15. Meridional profile of characteristic parameters (temperature, relative humidity, zonal wind and relative vorticity) at $700 \mathrm{mb}$ during the onset phase of season 1979 . 

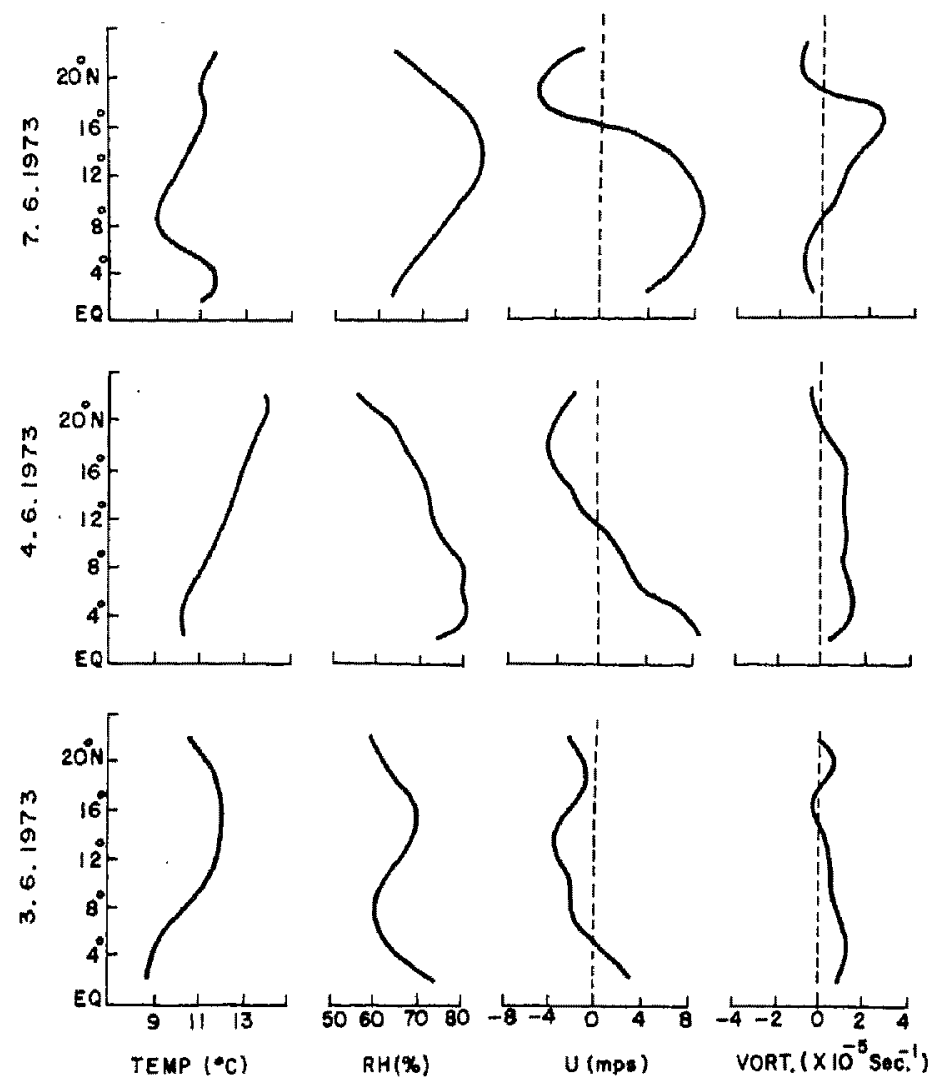

Figure 16. Meridional profile of characteristic parameters (temperature, relative humidity, zonal wind and relative vorticity) at $700 \mathrm{mb}$ during the onset phase of season of 1973 .

June 1973 define the conditions when the monsoon onset vortex had formed. The following features are observed:

(i) The axis of the IrCz progressively shifted northwards.

(ii) Air temperature increases from the equator towards $20^{\circ} \mathrm{N}$. The axis of the shear zone lies in the region of colder temperatures but to the north of it marked increase in temperature is observed.

(iii) Equatorial westerlies are more moist. As the shear zone intensifies, a nose (maximum) in the relative humidity profile develops at the axis of the shear zone. The gradient in the relative humidity profile to the north of the shear zone also increases with the intensification of the shear zone.

(iv) Progressive increase in the strength of the equatorial westerlies occurred between the pre-onset stage and the intensifying stage and the westerlies also extended northward.

(v) Relative vorticity is generally positive from 4 to $15^{\circ} \mathrm{N}$. The profile has a maximum which almost coincides with the axis of the shear zone and the magnitude of the maximum increases from about 1.5 units $\left(\times 10^{-5} \mathrm{sec}^{-1}\right)$ on 7 June to 5.0 units on 14 June 1979 and from 1 to 3 units during 3 to 7 June 1973 .

(vi) The weather observed during the research flight on 14 June 1979 across the shear 
zone showed deep convective clouds with moderate turbulence while crossing the shear zone. The rainfall over Kerala increased as the shear zone approached and lay near this area. Rainfall of 5 to $15 \mathrm{~cm}$ in $24 \mathrm{hrs}$ was reported over Kerala on 12 and 14 June.

5.1b Revival of monsoon after a 'break' monsoon in the established phase: Figures 17 and 18 show the meridional profile of different parameters (longitudinally averaged) at $700 \mathrm{mb}$ for three typical days representative of (i) early formative stage of the shears zone (21 July 1979 and 2 August 1973), (ii) well developed stage of the shear zone (24 July 1979 and 5 August 1973) and (iii) northward migrated shear zone located near $15^{\circ} \mathrm{N}$-the transition regime between the near equatorial location and the normal monsoon trough zone (26 July 1979 and 6 August 1973). The following features are observed.

(i) Temperature increases from south to north. However, the axis of the shear zone lies in the region of weak temperature gradient.

(ii) The maximum moisture zone lies about $2^{\circ}$ latitude to the south of the shear zone. Relative humidity increases from the formative to the intensified stage of the shear

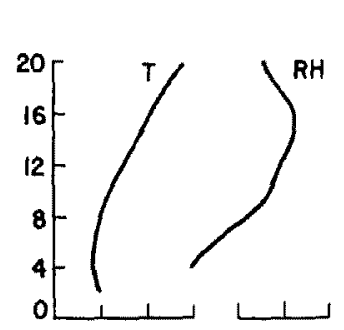

$26-7-1979$
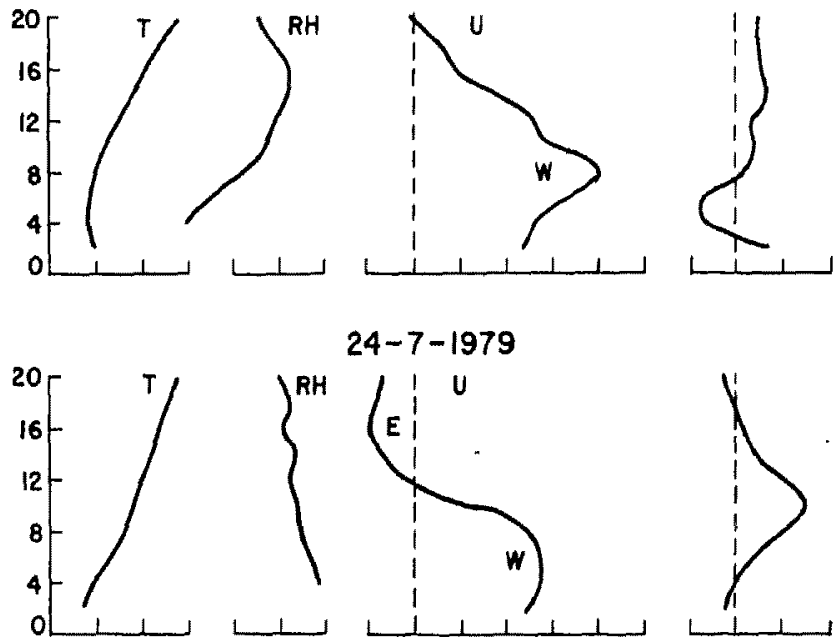

$24-7-1979$
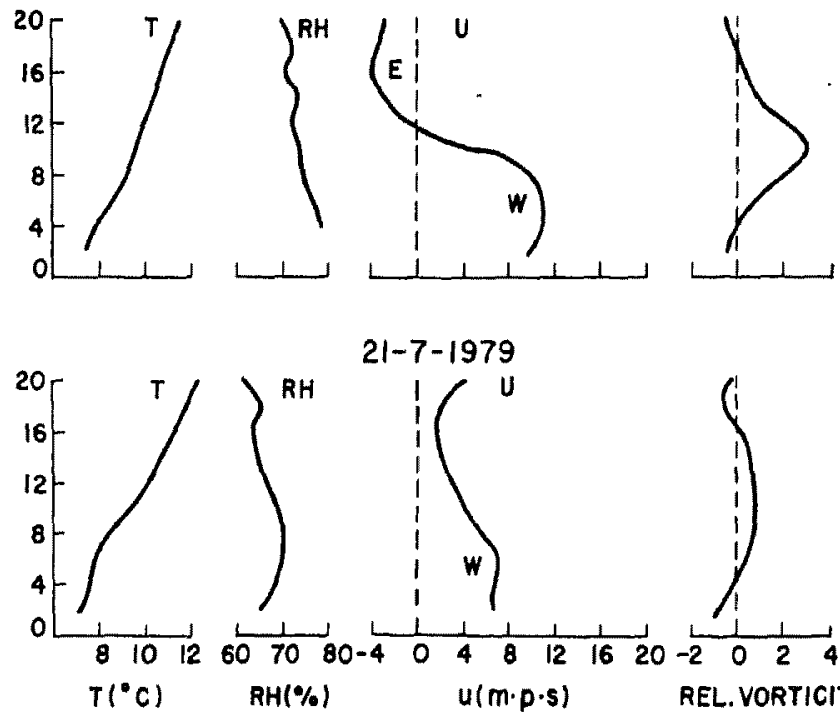

$$
21-7-1979
$$
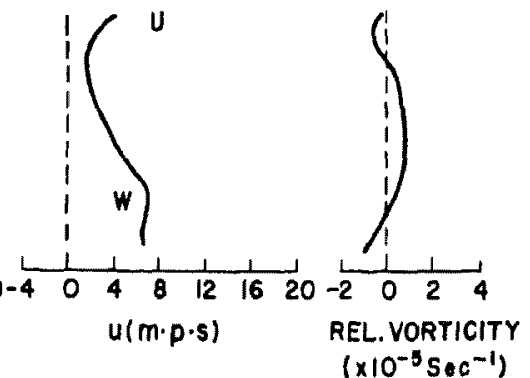

Figure 17. Meridional profile of characteristic parameters at $700 \mathrm{mb}$ during the revival of monsoon after a break in the established phase of season 1979. 

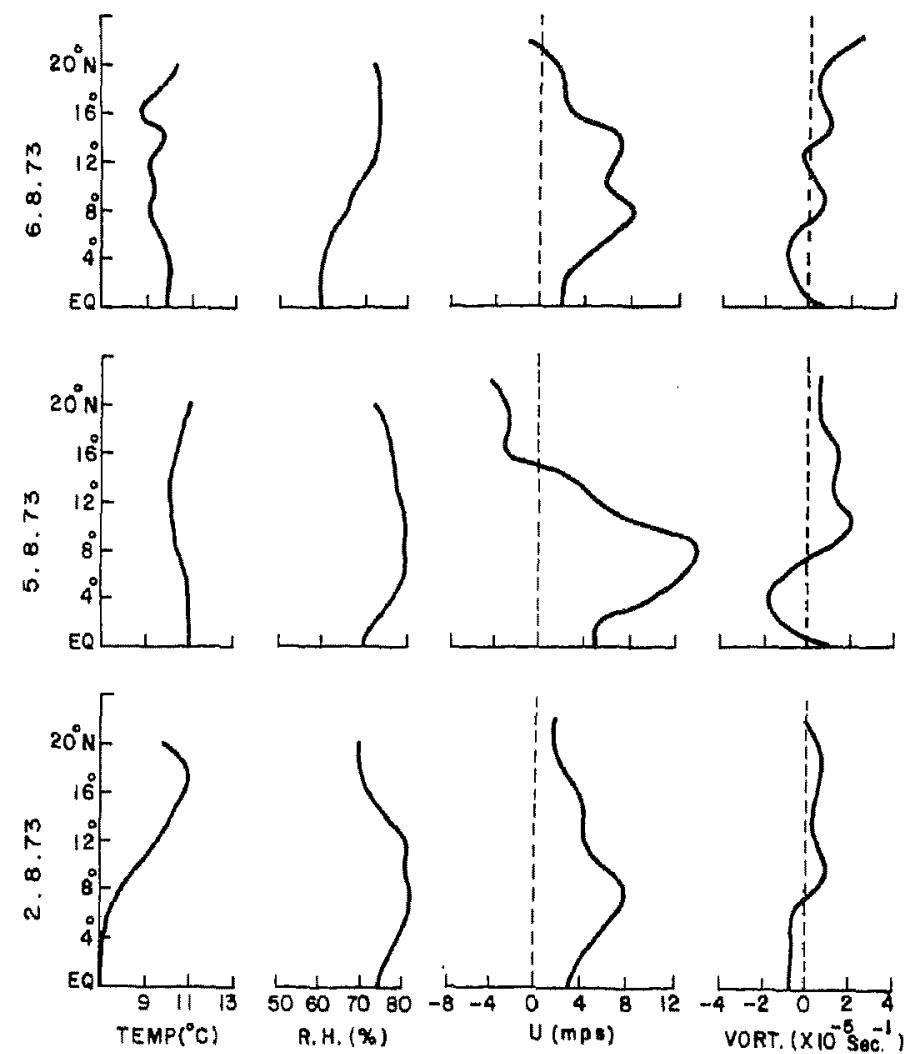

Figure 18. Meridional profile of characteristic parameters at $700 \mathrm{mb}$ during the revival of monsoon after a break in the established phase of the season of 1973 .

zone. On the third day, relative humidity has a maximum along $14^{\circ} \mathrm{N}$ in comparison to the maximum between $4-8^{\circ} \mathrm{N}$ seen on the other two days.

(iii) A region of weak cyclonic vorticity maximum of 0.5 units is observed between $6-12^{\circ} \mathrm{N}$ on the day of formation of the shear zone which intensified to about 2.5 units and became sharp along $12^{\circ} \mathrm{N}$ with the intensification of the shear zone. On the last stage, the region of cyclonic vorticity of about 1.0 units is observed between 9 to $20^{\circ} \mathrm{N}$ indicating the broad and diffuse nature of the longitudinally averaged vorticity profile.

\subsection{Disturbed state relative vorticity and divergence}

The disturbed state represents the average for the section of the large scale ITCZ covering the longitudes of the active zone of the disturbance. This has been studied with reference to relative vorticity and divergence for the 1979 cases only where ample data were available. The longitudinal belt chosen for averaging purposes is $66-72^{\circ} \mathrm{E}$ for the pre-onset and onset phases and $82-88^{\circ} \mathrm{E}$ for the revival phase.

(i) Pre-onset/onset phase-Figures $19 \mathrm{a}$ and $\mathrm{b}$ show the longitudinal time sections of the relative vorticity and divergence at $700 \mathrm{mb}$ during 4 to 14 June 1979 . The features 

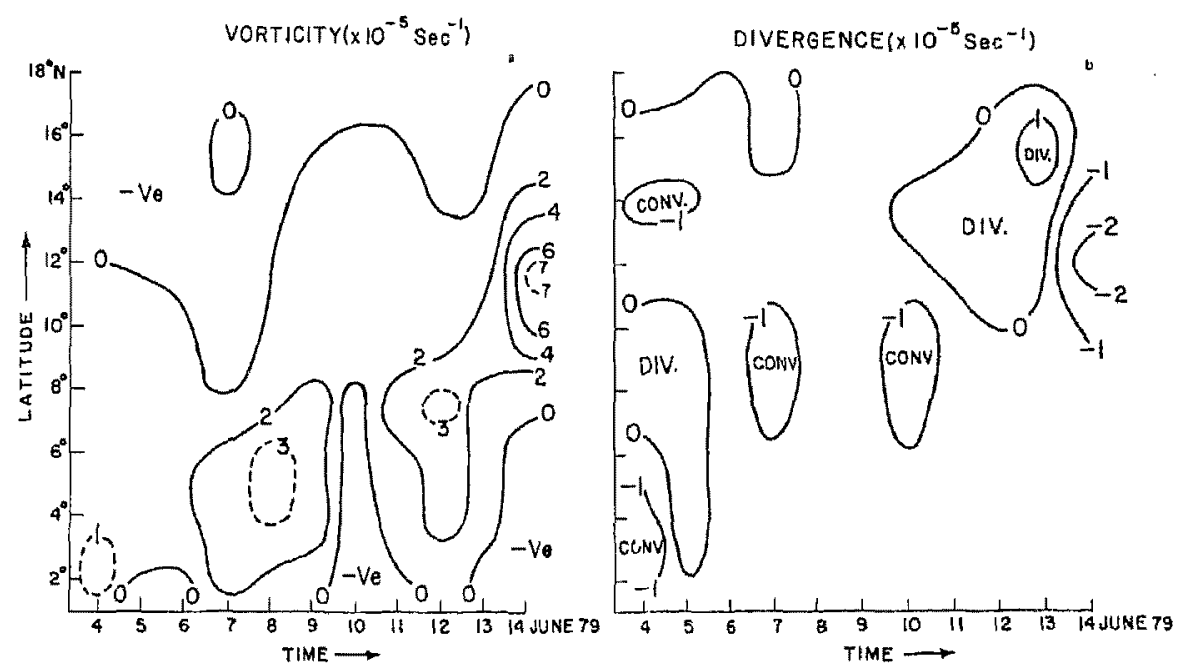

Flgure 19. Meridional-time section of a. relative vorticity and b. divergence at $700 \mathrm{mb}$ during 4-14 June 1979

on 8 June represent the disturbed phase on the pre-onset conditions (Bhide et al 1982). The features on 14 June represent the highly disturbed phase of the monsoon onset when the northward progression had begun.

Note that the relative vorticity maximum has shifted from $2^{\circ} \mathrm{N}$ on 4 June to $12^{\circ} \mathrm{N}$ on 14 June, the shift being rather rapid between 12 and 14 June. The maximum has also intensified to a value of 7.5 units on 14 June. Convergence of magnitude $\geqslant 1 \times 10^{-5} \mathrm{sec}^{-1}$ is observed in the vicinity (within about $2^{\circ}$ latitude) of the location of shear zone.

(ii) Revival phase-Figures $20 \mathrm{a}$ and $\mathrm{b}$ show the typical disturbed state parameters for the revival phase of the oceanic rrcz between 20 and 26 July 1979 .

\subsection{Vertical structure of the ITCZ}

Figure 21a shows the distribution of wind, temperature and relative humidity across different latitudes along approximately $65^{\circ} \mathrm{E}$ for the pre-onset conditions of the rTCZ typified by the data of 7 June 1979 . The same parameters along about $70^{\circ} \mathrm{E}$ are shown in figure $21 \mathrm{lb}$ for $14 \mathrm{June} 1979$, typical of the monsoon onset conditions of the Ircz. On $7 \mathrm{June}$ the ITCZ extends at best upto $700 \mathrm{mb}$ with a marked southward tilt as seen from its position along $12^{\circ} \mathrm{N}$ at $850 \mathrm{mb}$ and about $4^{\circ} \mathrm{N}$ at $700 \mathrm{mb}$. On 14 June the IrCZ extended upto $400 \mathrm{mb}$ without any significant slope between 850 and $400 \mathrm{mb}$. The horizontal shear across the axis also considerably increased as the equatorial westerlies strengthened to the south. The moist layer ( $\geqslant 80 \%$ relative humidity) also considerably deepened from $850 \mathrm{mb}$ on 7 June to at least $400 \mathrm{mb}$ on 14 June. There is also appreciable fall in temperature $\left(3\right.$ to $\left.4^{\circ} \mathrm{C}\right)$ north of $10^{\circ} \mathrm{N}$ at 850 and $700 \mathrm{mb}$ and increase of about $2^{\circ} \mathrm{C}$ at $400 \mathrm{mb}$ from the pre-onset ( 7 June) to the onset conditions ( 14 

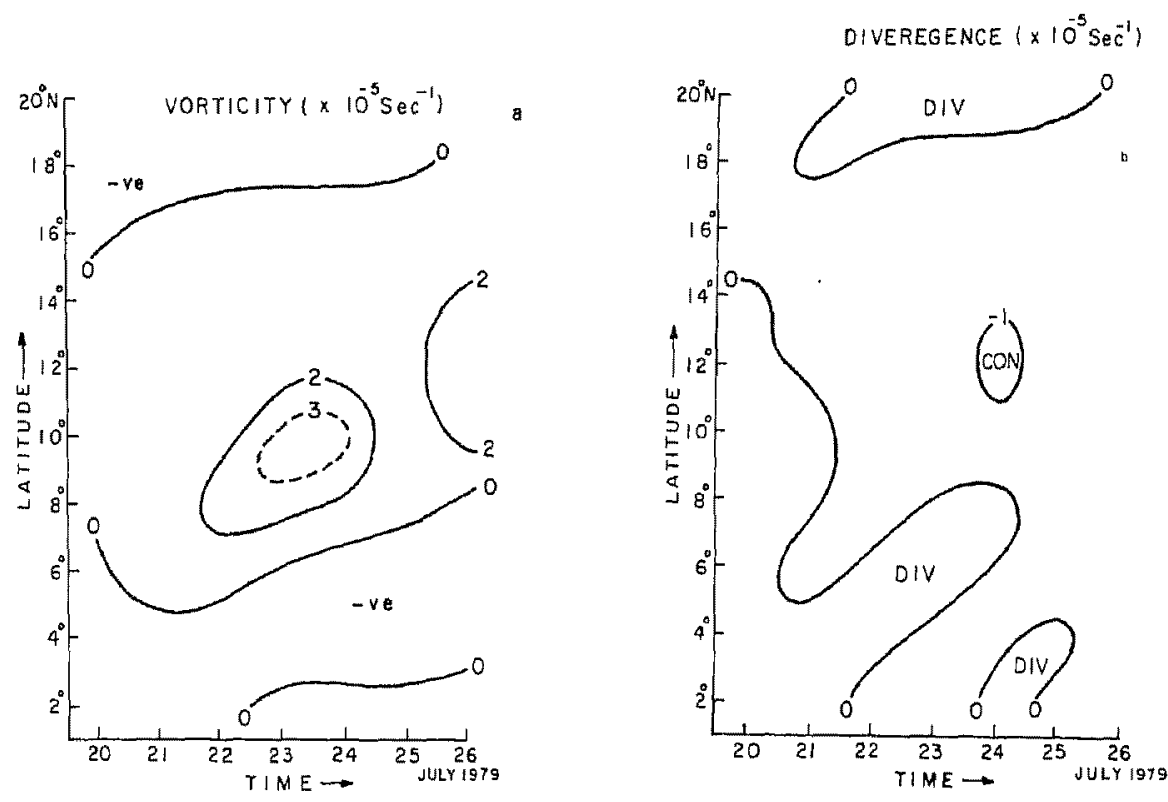

Figure 20. Meridional-time section of a. relative vorticity and b. divergence at $700 \mathrm{mb}$ during 20-26 July 1979 .

7 JUNE 1979

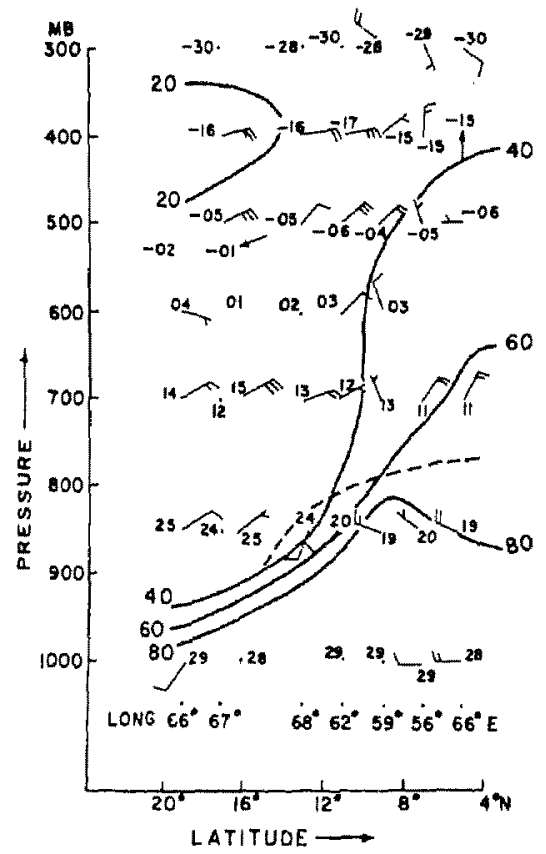

14 JUNE 1979

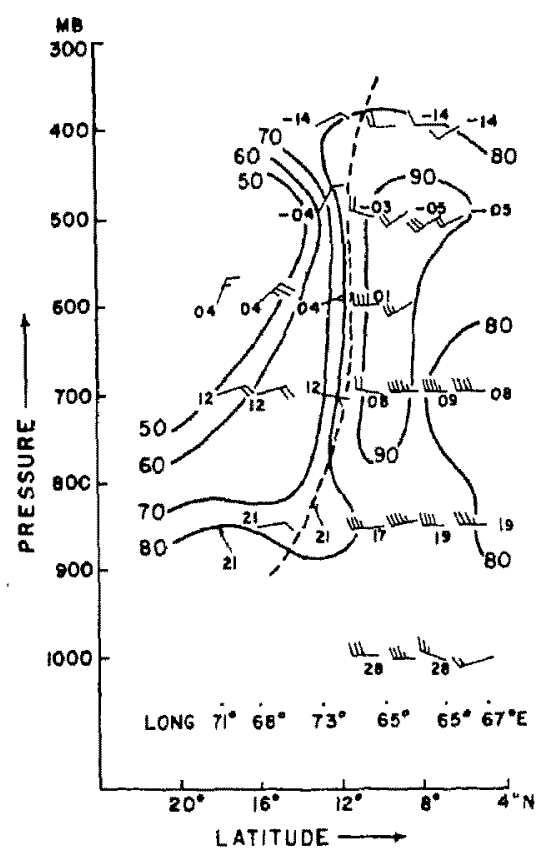

Figure 21. Meridional section in the vertical of wind, temperature and relative humidity (approximately along $65^{\circ} \mathrm{E}$ ) based on data collected during research flights on 7 and $14 \mathrm{June}$ 1979. 


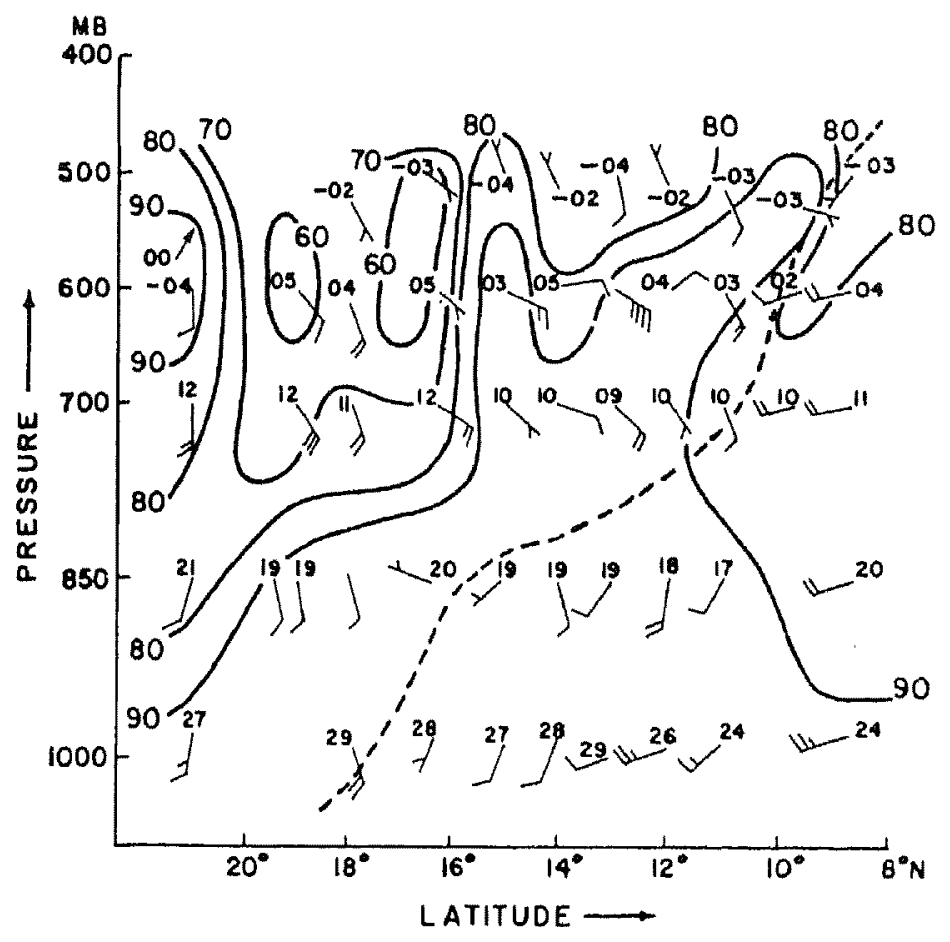

Figure 22. Meridional section in the vertical of wind, temperature and relative humidity (approximately along $70^{\circ} \mathrm{E}$ ) based on data collected during a research flight on 24 July 1979.

June). These temperature changes are indicative of the large scale convective activity as the system intensified.

The vertical structure of the well developed near equatorial oceanic ITCZ in the Bay of Bengal during the revival phase of the monsoon for 24 July 1979 is shown in figure 22. The shear zone has a very large vertical slope between 1000 and $700 \mathrm{mb}$. Strong westerly flow is to the south of $12^{\circ} \mathrm{N}, 10^{\circ} \mathrm{N}$ and $8^{\circ} \mathrm{N}$ at 1000,700 and $600 \mathrm{mb}$ respectively. The temperature gradient is small across the shear zone at 700 to $400 \mathrm{mb}$. A deep moist layer (relative humidity, $\mathrm{RH} \geqslant 80 \%$ ), extending upto $500 \mathrm{mb}$, prevails in the vicinity of the shear zone between 9 and $16^{\circ} \mathrm{N}$. The second maximum in the RH, which is observed near $21^{\circ} \mathrm{N}$ is perhaps due to the day-time cumulus activity over the marshy continental region adjoining the Northern Bay of Bengal.

\section{Summary}

Based on the synoptic analysis of the weather events for the two typical summer monsoon seasons of 1979 (Monex) and 1973 (ISMEX) chiefly at $700 \mathrm{mb}$ and the satellite imagery, intra-seasonal fluctuating regimes of different phases of the summer monsoon system over the Indian region are described. The following aspects have been brought out by the study.

(i) The analysis has confirmed that the major phase changes in the sub-seasonal scale 
are characterised by two preferred positions of the ITCZ, viz, (a) near equatorial one $\left(5-10^{\circ} \mathrm{N}\right)$, in the beginning of the season and also soon after the 'break' monsoon conditions, and (b) continental one $\left(20-25^{\circ} \mathrm{N}\right)$ during the established phase of the monsoon. The transition between the near equatorial oceanic position to the continental position is brought about during the onset and mid-season revival of the monsoon by northward propagation of the near equatorial oceanic rTCZ to take the position normally occupied by the monsoon trough.

(ii) The analysis also confirmed that the major phase changes in the ITCZ occur at an interval of about 30-50 days in the monsoon season.

(iii) The northward migration is initiated by the strengthening of the equatorial westerlies which result in the intensification of the shear zone.

(iv) The active phase of the monsoon in the middle of the season which lasts for 15-20 days is enveloped by the formation of overlapping disturbances (low pressure areas, depressions, mid-tropospheric cyclonic systems) in the vicinity of the regional monsoon trough extending from $70^{\circ} \mathrm{E}$ to $95^{\circ} \mathrm{E}$ over the monsoon trough region. The movement of the trough from $25^{\circ} \mathrm{N}$ to the foothills is accomplished rather rapidly (about 2-3 days).

(v) The 'break' monsoon phase in which the monsoon trough moves close to the foothills of the Himalayas and the near equatorial trough gets emphasised, lasts for about $5-10$ days. The changeover from the rrcz from about $15^{\circ} \mathrm{N}$ to $20^{\circ} \mathrm{N}$ is again accomplished somewhat rapidly ( $2-3$ days).

(vi) The large scale oceanic ITCZ is characterised by: (a) cyclonic vorticity over the entire belt at the beginning of the onset phase. As the equatorial westerlies strengthen and the disturbance intensifies a region of anticyclonic vorticity is noticed to the south of the axis of the maximum wind. The cyclonic vorticity over the perturbed part of the ITCZ at the intensifying stage, is about 3 to 4 times the large scale magnitude. The cyclonic vorticity also extends in the vertical up to about $400 \mathrm{mb}$ at the intensifying stage; (b) deep moist layer extending upto even $400 \mathrm{mb}$ prevails in the vicinity of the disturbed portion of ITCz; (c) temperature is colder in the layer 850 to $700 \mathrm{mb}$ in the vicinity of ITCZ in comparison to the environment and it increases to the north of the axis of the ITCZ.

\section{Acknowledgement}

The authors are thankful to Dr Bh V Ramana Murty, for his interest in the study.

\section{References}

Bhide U V, Nagar S G and Sikka D R 1982 Proc. Int. Conf. on Scientific results of Monsoon Exp., Bali, Indonesia, 26-31 October, 1981, pp. 3-69 to 3-73 wMO, Geneva

Godbole R V and Ghosh S K 1975 Tellus 27123

Koteswaram P 1950 Indian J. Meteorol. Geophys. 1162

Krishnamurty T N, Philip Ardanuy, Ramanathan Y and Pasch Richard 1981 Mon. Weather Rev. 109344

Krishnamurty T N and Subrahmanyam D 1982 J. Atmos. Sci. 392088

Krishnamurty T N and Ramnathan Y 1982 J. Atmos. Sci. 391290

Mukherjee A K and Natarajan G 1968 Indian J. Meteorol, Geophys. 19286 
Murakami T, Tetuso Nakazawa and Jinhai He 1983 Dept. of Meteol. University of Hawaii, uHMET 83-02, p. 133

Sikka D R and Gadgil S 1980 Mon. Weather Rev. 1081840

WMO 1976 The monsoon experiment, GARP publication series no. 18, World Meteorological Organisation. Sikka D R 1981 FGGE Operations Report, Vol. 9, pp. 87-95

Yasunari T 1979 J. Meteorol. Soc. Jpn 57227

Yasunari T 1980 J. Meteorol. Soc. Jpn 58225

Yasunari T 1981 J. Meteorol. Soc. Jpn 59339 